\title{
Southern elephant seal foraging success in relation to temperature and light conditions: insight into prey distribution
}

\author{
Christophe Guinet ${ }^{1, *}$, Jade Vacquié-Garcia ${ }^{1}$, Baptiste Picard ${ }^{1}$, \\ Guillaume Bessigneul ${ }^{1}$, Yves Lebras ${ }^{1}$, Anne Cécile Dragon ${ }^{1,2}$, Morgane Viviant ${ }^{1}$, \\ John P. Y. Arnould ${ }^{3}$, Frédéric Bailleul ${ }^{1}$ \\ ${ }^{1}$ Centre d'Etudes Biologiques de Chizé, CNRS, 79360 Villiers en Bois, France \\ ${ }^{2}$ LOCEAN-UPMC, 4 Place Jussieu, Boite 100, 75252 Paris Cedex 05, France
}

${ }^{3}$ School of Life and Environmental Sciences, Faculty of Science \& Technology, Deakin University, 221 Burwood Highway, Burwood, VIC 3125, Australia

\begin{abstract}
The distribution of southern elephant seal Mirounga leonina prey encounter events (PEEs) was investigated from the foraging behaviour of 29 post-breeding females simultaneously equipped with a satellite tag, a time-depth recorder and a head-mounted accelerometer. Seal diving depth and PEE were related to water temperature at $200 \mathrm{~m}\left(T_{200}\right)$, and light level at the surface $\left(L_{0}\right)$ and at depth. Approximately half $(49 \%)$ of all dives were located in waters encompassed between the southern Antarctic Circumpolar Current Front and the Polar Front. Seals dived significantly deeper during the day than at night. Diving and PEE depth increased with increasing $T_{200}$ and for a given $T_{200}$ according to $L_{0}$ and the percentage of surface light reaching $150 \mathrm{~m}$. On average, 540 PEEs per day were recorded. Seals exhibited more PEEs per unit of time spent diving during the twilight period compared with at night, and were least successful during daylight hours. Elephant seals forage in $T_{200}$ ranging between -1 and $13^{\circ} \mathrm{C}_{i}$ however, few PEEs were recorded at depths shallower than $400-500 \mathrm{~m}$ at night when the $T_{200}$ exceeded $8^{\circ} \mathrm{C}$. The diet of female Kerguelen elephant seals appears to be dominated by myctophids (lanternfish), and according to the average mass of their most likely myctophid prey $(9 \mathrm{~g}$, Electrona calsbergi and $E$. antarctica; $30 \mathrm{~g}$ Gymnoscopelus nicholsi and G. piabilis), we estimate that seals consumed $4.8-16.1 \mathrm{~kg}$ of fish daily. Despite lower catch rates in warmer waters, no relationship was found between the mean $T_{200}$ at the scale of the foraging trip and daily or absolute mass gain, suggesting that elephant seals are compensating for lower catch rates by consuming larger/richer prey items in those waters.
\end{abstract}

KEY WORDS: Southern elephant seals $\cdot$ Foraging success $\cdot$ Light $\cdot$ Temperature $\cdot$ Diving behaviour · Prey

Resale or republication not permitted without written consent of the publisher

\section{INTRODUCTION}

An increasing number of studies show that, along with the measurement of concomitant oceanographic data, the behaviour of top marine predators can provide valuable insights into the habitat in which they forage (e.g. Biuw et al. 2007, 2010). Accordingly, the development of miniaturised electronic devices has opened a new era of research on the foraging behaviour of marine predators and allows the acquisition of huge quantitative data sets of behaviour from animals moving freely in their natural environment (Ropert-Coudert \& Wilson 2005). Behavioural (location, diving depth, prey capture) and environmental 
(temperature, salinity, light, fluorescence) parameters can be continuously recorded by high-resolution multi-channel data loggers. This enables studies of the conditions under which animals live, as well as the ability to monitor their environment (Boehlert et al. 2001).

Among top marine predators, air-breathing diving species such as seals are particularly well-suited for the bio-acquisition (i.e. bio-logging) of movement, behavioural, physiological as well as environmental data using miniaturised animal-attached tags (Rutz \& Hays 2009). Their large size allows them to carry electronic devices with minimal disturbance, and researchers can handle them while they are on land in their breeding colonies. Furthermore, while investigating at-sea seal ecology, measurements of oceanographic parameters within the water column have also been obtained. Consequently, foraging, diving predators have provided new and original information about physical (Charrassin et al. 2008, Costa et al. 2008, Roquet et al. 2009) and biological oceanography (Guinet et al. 2013) in often inaccessible regions.

In recent years, one of the most exciting applications of bio-logging is the determination of the distribution and availability of prey of which we have very little knowledge. Until recently, the main limitation was an in situ measure of direct prey ingestion. Early devices to record predation events of seabirds and marine mammals included stomach (Wilson et al. 1992) and oesophageal temperature sensors (Ancel et al. 1997, Charrassin et al. 2001), which detected temperature changes induced by prey ingestion. However, these temperature loggers have certain limits, as they are restricted to endotherms feeding on ectothermic prey and are quite invasive. Furthermore, stomach temperature recorders fail to detect multiple rapid ingestions of small prey and are often regurgitated prematurely (Ropert-Coudert et al. 2004, Liebsch et al. 2007). External loggers such as the Inter-Mandibular Angle Sensor (IMASEN) record the mouth-opening angle of predators (Wilson et al. 2002), but are sometimes difficult to apply on animals with flexible lips (Ropert-Coudert et al. 2004, Liebsch et al. 2007). Recent studies in free-ranging diving pinnipeds have overcome this methodological issue by using head- or jaw-mounted accelerometers to detect prey encounter events (PEEs) (Suzuki et al. 2009, Naito et al. 2010, 2013, Viviant et al. 2010, Gallon et al. 2013, Iwata et al. 2012). This has enabled investigations into fine-scale temporal and spatial changes in the foraging of an increasing number of pinniped species, including the southern elephant seal Mirounga leonina (SES hereafter) - the largest and deepest-diving pinniped.

Both its abundance and body mass make the SES a major consumer of Southern Ocean (SO) marine resources (Guinet et al. 1996, Hindell et al. 2003). It was previously thought that SES primarily fed on squid, but a recent isotopic investigation challenged this view and, instead, indicated that female SES from the Kerguelen Islands mainly feed on myctophid fish (i.e. lanternfish) (Cherel et al. 2008). Indeed, myctophid (the abundant Electrona antarctica, E. carlsbergi and Gymnoscopelus nicholsi) otoliths have been found in stomachs of SES from the Kerguelen sector (Slip 1995) and elsewhere (Daneri \& Carlini 2002).

Satellite tracking data show that SES are broadranging animals during their post-breeding and postmoult migrations, with adult females from the Kerguelen Islands foraging mainly in oceanic waters of the Antarctic and Polar Frontal Zones (Bailleul et al. 2010). While at sea, SES dive repeatedly to mesopelagic depths (300-500 m, up to $2000 \mathrm{~m}$ ) and tend to follow the nycthemeral vertical migration of their mesopelagic prey, diving generally deeper during the day (Hindell et al. 1991, McIntyre et al. 2010). In a recent study, Jaud et al. (2012) found that light level at depth explained $70 \%$ of the variation in diving depth of the SES during daylight hours while no significant effect was detected at night. Furthermore, light level at depth in oceanic waters was explained to a large extent by phytoplankton concentration: the higher the phytoplankton concentration, the less light and the shallower the dives of SES (Jaud et al. 2012).

The objectives of this study were to investigate the variation in diving behaviour and prey encounter event rates of female SES to better characterise their prey in terms of likely size and distribution according to environmental conditions such as sea temperature and light level along a north-south gradient ranging from subtropical waters to Antarctica.

\section{MATERIALS AND METHODS}

\section{Animal handling and instrumentation}

During October/November each year from 2008 to 2012, post-breeding SES females were captured on the Kerguelen Islands $\left(49^{\circ} 20^{\prime} \mathrm{S}, 70^{\circ} 20^{\prime} \mathrm{E}\right)$. Individuals were anaesthetised using a 1:1 combination of tiletamine and zolazepam (Zoletil 100), which was injected intravenously (McMahon et al. 2000). In general, post-breeding females forage at sea for durations 
varying from 65 to $80 \mathrm{~d}$, departing late October before returning to land throughout January to moult. A total of 34 SES females were equipped with a range of satellite tags and data loggers (see Table 1).

Eighteen seals were equipped with GPS loggers in combination with Argos satellite loggers and archival data loggers (SPLASH10-Fast-Loc GPS, Wildlife Computers). SPLASH10 devices transmitted Argos location data and collected GPS location data. The sampling interval of GPS locations was set to a minimum of $20 \mathrm{~min}$, slightly shorter than the average dive duration of post-breeding females (Hindell et al. 1991, McIntyre et al. 2011a), to maximise the chance of obtaining a GPS location every time individuals surfaced between dives. An additional logger, a timedepth recorder (TDR) included in the SPLASH10 devices, collected and archived pressure, light and temperature levels at 1 or $2 \mathrm{~s}$ intervals.

Sixteen seals were equipped with conductivitytemperature-depth satellite-relay data loggers (CTD-SRDLs, Sea Mammal Research Unit, University of St Andrews) combined with either TDR loggers (MK9, Wildlife Computers), set to sample and archive pressure, light and temperature levels every 1 or $2 \mathrm{~s}$, or TDR-accelerometer data loggers (MK10$\mathrm{X}$, Wildlife computers), sampling acceleration as well as pressure. The acceleration was measured on 3 axes: longitudinal (surge), vertical (heave) and lateral (roll) axes were used to separate dynamic accelerations from gravitational acceleration. Acceleration was sampled at $16 \mathrm{~Hz}$ and pressure every second.
The SPLASH 10, MK10-X and MK9 TDR loggers were set to sample depth $(0-1500 \mathrm{~m}, \pm 1 \mathrm{~m})$, water temperature $\left(-40\right.$ to $\left.+60^{\circ} \mathrm{C}, \pm 0.1^{\circ} \mathrm{C}\right)$ and light $(5 \times$ $10^{-2}$ to $5 \times 10^{-12} \mathrm{~W} \mathrm{~cm}^{-2}$ in blue wavelength) every 1 or $2 \mathrm{~s}$. Light values are converted on-board via a log transformation to compress the light measurements to a 3 digit value.

Data loggers were glued on the head of the seals, using quick-setting epoxy (Araldite AW 2101, Ciba), after cleaning the fur with acetone. Upon returning from their foraging trip, females were located via Argos data, recaptured and weighed, and loggers were retrieved.

\section{Data processing and analysis}

Female SES from the Kerguelen Island population forage mainly in pelagic waters but also to a lesser extent on the Kerguelen and Antarctic continental shelves (i.e. the main foraging habitat of Kerguelen Island sub-adult and adult males; Bailleul et al. 2010, Dragon et al. 2010, Authier et al. 2012). As part of this work we focused on the pelagic portion of the tracks by excluding data from areas where water depths were $<1000 \mathrm{~m}$ (Fig. 1), based on National Geophysical Data Centre ETOPO2 Global 2 Elevations (www.ngdc.noaa.gov/mgg/global/etopo2.html), to exclude all locations on the Kerguelen and Crozet plateaus where SES are known to conduct benthic dives (Bailleul et al. 2010).

Pressure sensor data were analysed from MK9 and SPLASH10 TDRs to obtain dive depth profiles. For the purpose of this study, and based on the sensor's absolute accuracy, only excursions below a depth of $15 \mathrm{~m}$ were analysed. Bottom depth, light and the temperature profiles associated with each dive were extracted (see Dragon et al. 2012 for details). Each dive was divided into a descent, ascent and bottom phase. The bottom phase corresponds to the period between the end of the descent and the beginning of the ascent. The different dive phases were defined according to Dragon et al. (2012) using a custom-written MATLAB code (version 7.0.1; available on request). In the present study, the diving depth is defined as the mean depth during the bottom phase of the dive.
Fig. 1. Tracks of the 29 post-breeding southern elephant seal females for which high-resolution data were recovered. The blue section of track corresponds to the period when accelerometry data were collected. The main frontal structures are reported from south to north: Antarctic divergence (red), Southern Antarctic Circumpolar Current Front (black), Polar Front (blue), Subantarctic Front (orange) and the Subtropical Front (green). Shelf area from the coast to the $-1000 \mathrm{~m}$ isobaths is indicated in grey 
Data from the accelerometer were processed according to Viviant et al. (2010) and Gallon et al. (2013) using custom-written MATLAB code (available on request). Identifying individual feeding events from the accelerometry data was performed according to the following procedures. Firstly, the 3 accelerometer time series were filtered with a highpass filter of 0.33 critical frequency for data sampled at $16 \mathrm{~Hz}$ to remove the remaining noise corresponding to swimming movement, highlighting the peaks in acceleration that represent head movements. Rapid head movements were used to identify possible PEEs. The 0.33 filter was defined visually on power spectral density of acceleration on the 3 axes.

Secondly, the standard deviation along a fixed $1 \mathrm{~s}$ window over each time series axis was calculated to sum accelerations at a $1 \mathrm{~s}$ scale. The standard deviation along a $5 \mathrm{~s}$ moving window, over each standard deviation time series, was then calculated for each axis to highlight extreme standard deviation and consequently significant accelerations. The threshold distinguishing those extreme events was defined using the kmeans function (MATLAB, tool box statistics) and was calculated for each seal and for each axis independently. Only head movement events that could be detected simultaneously on the 3 axes were considered as a true PEE; others were considered to be related to dives where animals did not alter their swimming behaviour whilst travelling underwater. Continuous values at $1 \mathrm{~Hz}$ above the threshold were considered as unique PEEs. Events separated by periods longer than $1 \mathrm{~s}$ below the threshold value for any given axes were considered as a different PEE. The number, timing and depth location of PEEs were determined for each dive. In the present study, a PEE does not mean that the seal was feeding with certainty, but should be considered as a relative index of a prey encounter during the dive.

From these data we then calculated PEE per unit time (PEE rate) at 2 scales: (1) the complete dive and (2) the bottom phase of the dive. The latter removes the effect of the vertical accessibility of the prey, since a seal has to undertake a longer vertical transit when it dives deeper and consequently has less time to spend at the bottom of the dive (i.e. where most PEEs are expected to occur).

For each animal, the temperature profile associated with each dive was extracted from MK9, TDR10-X and SPLASH 10 TDR data. At any given latitude, but different longitudes, water masses with very different temperature profiles can be observed depending on the location of the main frontal structures (see Fig. 1). Dives were therefore ranked re- gardless of their latitude, in a decreasing order, according to their water temperature at $200 \mathrm{~m}\left(T_{200}\right)$, to reflect a general north-south gradient. Profiles were then regrouped into $1^{\circ} \mathrm{C} T_{200}$ classes. Each $1^{\circ} \mathrm{C}$ class was defined according to its lower boundary (i.e. $-1^{\circ} \mathrm{C}$ defining the $\left[-1^{\circ} \mathrm{C} ; 0^{\circ} \mathrm{C}\right.$ temperature class). Then, for all the dives belonging to a given $T_{200}$ class, the mean temperature for 5-m depth bins was calculated over the whole depth range. This provides a mean temperature profile for a given temperature scenario at $200 \mathrm{~m}$. These mean temperature profiles were used for figure representation and statistical comparisons between the different $1^{\circ} \mathrm{C} T_{200}$ classes: day-night difference in the mean diving depth and comparison of PEEs per minute spent diving or spent at the bottom of the dive. Dives shallower than $200 \mathrm{~m}$ were allocated to a $T_{200}$ category according to the $T_{200}$ encountered during previous and/or following dives with a diving depth exceeding $200 \mathrm{~m}$.

The SO fronts are narrow regions of sharp horizontal gradients of water properties that mark the boundaries of different water masses (Fig. 1). These structures are defined by representative values of temperature and salinity at approximately $200 \mathrm{~m}$ depth, where each front is generally best marked. The water mass the seal was diving in was identified using the $T_{200}$, as indicated by Park et al. $(1991,1998)$ and Orsi et al. (1995). Going north from the Antarctic continent, the Antarctic Divergence (AD) has been identified with the most shoreward penetration of the $0.8^{\circ} \mathrm{C}$ isotherm at depths below the Winter Water. The Southern Antarctic Circumpolar Current Front (SACCF) is defined by a temperature of $1.6^{\circ} \mathrm{C}$ and a salinity of 34.6 PSU at $200 \mathrm{~m}$ depth (Park et al. 1998). The Polar Front (PF) is approximated by the northern limit of the subsurface temperature minimum of $2.8^{\circ} \mathrm{C}$ at the 100-300 m depth layer (Park et al. 1993, Belkin \& Gordon 1996). Although the Subantarctic Front (SAF) is less well defined, values of $6.8^{\circ} \mathrm{C}$ are considered as subsurface expressions of this front in the Indian sector (Park et al. 1993) and, therefore, we used $7^{\circ} \mathrm{C}$ at $200 \mathrm{~m}$ as the SAF limit. Values of $10.8^{\circ} \mathrm{C}$ at $200 \mathrm{~m}$ depth are adopted to define the Subtropical Front (STF) (Park et al. 1993); therefore, we used $11^{\circ} \mathrm{C}$ at $200 \mathrm{~m}$ as the STF limit in this study. We defined the Polar Frontal Zone as the area located between the STF (northern limit) and the PF (southern limit), and the Antarctic Circumpolar Current (ACC) zone is defined as the area between the SAF and the SACCF.

Light levels within the water column vary greatly according to a number of factors, such as sun angle, cloud cover and phytoplankton concentration within oceanic waters. This latter factor explains approxi- 
mately $50 \%$ of the variation of light attenuation within the water column (Jaud et al. 2012). For each dive record from the MK9, MK10 X and SPLASH10 TDR data, we calculated the level of light available at each depth measurement along the entire dive. Surface light level $\left(L_{0}\right)$ was calculated as the mean light reading during the surface interval after the dive. The percentage of surface light reaching $150 \mathrm{~m}$ $\left(L_{150} / L_{0}\right)$, corresponding in general to the euphotic depth in the SO (Knox 2007), was calculated during the ascent phase of the dive prior to surfacing. To assess the effect of phytoplankton and particle concentration on light level available at depth, light at depth was expressed as a percentage of $L_{0}$.

Each dive was attributed to one of 3 periods: day, night or twilight. This was defined according to the solar angle, taking into account the geographical location of the seal provided by the Argos/GPS data and the time at the beginning of the dive. Day was defined when the sun was above the horizon $\left(0^{\circ}\right)_{\text {i twilight, }}$ when the sun was between $0^{\circ}$ and $6^{\circ}$ below the horizon $_{i}$ and night, when the sun was more than $6^{\circ}$ below the horizon. The twilight period used in our study corresponds to civil dawn and dusk, i.e. the time at which there is enough light for objects to be distinguishable in the air and the light is therefore likely to influence the vertical distribution of biological organisms within the water column. The sun angle according to the geographical location and time was calculated using the suncycle function in MATLAB.

\section{Statistical analyses}

The relationships between (1) bottom duration according to dive duration and diving depth, (2) dive duration according to $T_{200}$, diving depth, the number of days elapsed since departure from the colony, $L_{0}$, $L_{150} / L_{0}$ for day, night and twilight periods and (3) the mean depth at the bottom of the dive and PEE depth according to $T_{200}, L_{0}$ and $L_{150} / L_{0}$ for day and night (the same analysis was performed north and south of the SAF, i.e. for $T_{200}$ higher and lower than $7^{\circ} \mathrm{C}$ ) were analysed using a linear mixed model (package nlme in $R_{i} R$ Development Core Team 2009). Light level analyses were performed only during day and night. Indeed during twilight, light level varies to a great extent and is known to induce very large variation in elephant seal diving behaviour. Instead, this study aimed to assess whether female SES diving behaviour responds to small changes in $L_{0}$ and $L_{150} / L_{0}$ during either the day or the night. The variation in PEE according to diving depth, with dive duration or bot- tom time accounted for in the model, was analysed using a generalised linear mixed model with multivariate normal random effects, using penalized quasi-likelihood (package GlmmPQL in $\mathrm{R}_{i} \mathrm{R}$ Development Core Team 2009) on night, day and twilight separately. Individual seal was included as a random factor to take into account inter-individual variability. An autoregressive variance-covariance matrix (cor AR1 in $R_{i}$ R Development Core Team 2009) representing first-order autocorrelation structure was used to model the serial correlation among observations for each individual (Zuur et al. 2009). All variables were standardised (centred and scaled) to facilitate model convergence and to be able to compare the respective contribution of the predictors (Zuur et al. 2009). Using GLmmPQL, model selection can only be performed according to $\mathrm{p}$-values. We implemented a stepwise procedure, with the threshold set at $\mathrm{p}=$ 0.05 . Data are presented as means $\pm \mathrm{SD}$. The variation in PEE rate throughout the dive and at the bottom of the dive and according to $T_{200}$ classes was compared between day, night and twilight using a Wilcoxon test.

\section{RESULTS}

The mean mass and length of the 34 post-breeding females prior to their departure were $296 \pm 54 \mathrm{~kg}$ and $242 \pm 15 \mathrm{~cm}$, respectively. Among these 34 equipped seals, all but 3 were recaptured and high-resolution diving data were successfully recovered for 29 of 31 remaining females. The mean foraging trip duration was $82 \pm 9 \mathrm{~d}(\mathrm{n}=31$; Table 1$)$, the mean recovery mass was $363 \pm 55 \mathrm{~kg}(\mathrm{n}=25)$; therefore, the mean overall mass gain was $75 \pm 36 \mathrm{~kg}$ while the daily mass gain was $0.9 \pm 0.4 \mathrm{~kg}$ per day spent at sea $(\mathrm{n}=25$; Table 1$)$.

The tracks of the 29 SES females for which we had high-frequency measurements of pressure, temperature and light are shown in Fig. 1. These tracks extended from the subtropical zone to the Antarctic shelf. On average, SES performed $66 \pm 9$ dives daily. Among those, PEE data were obtained for 12 SES along their track (see Fig. 1, Table 1). An example of data obtained for one complete foraging trip is presented in Fig. 2.

\section{Dive, light and temperature distribution}

Seals ranged from the AD to the STF front (Figs. 1 \& 3). Among the 106313 dives performed by the 29 post breeding SES females, 62.2, 29.9 and $7.9 \%$ 
Table 1. Female southern elephant seal identity, deployment and recovery dates, foraging trip duration, mass, standard body length, mean $200 \mathrm{~m}$ temperature $\left(T_{200}\right)$ and equipment type deployed

\begin{tabular}{|c|c|c|c|c|c|c|c|c|c|c|c|c|c|}
\hline Seal ID & Deployment & Recovery & $\begin{array}{l}\text { Trip } \\
\text { (d) }\end{array}$ & $\begin{array}{c}\text { Departure } \\
\text { mass } \\
(\mathrm{kg})\end{array}$ & $\begin{array}{c}\text { Return } \\
\text { mass } \\
(\mathrm{kg})\end{array}$ & $\begin{array}{l}\text { Mass } \\
\text { gain } \\
(\mathrm{kg})\end{array}$ & $\begin{array}{l}\text { Daily } \\
\text { mass gain } \\
(\mathrm{kg})\end{array}$ & $\begin{array}{l}\text { Length } \\
(\mathrm{cm})\end{array}$ & $\begin{array}{l}T_{200} \\
\left({ }^{\circ} \mathrm{C}\right)\end{array}$ & $\begin{array}{c}\text { Argos- } \\
\text { CTD }\end{array}$ & $\begin{array}{c}\text { Splash- } \\
10-\mathrm{F}\end{array}$ & $\begin{array}{l}\text { TDR- } \\
\text { MK9 }\end{array}$ & $\begin{array}{c}\text { TDR- } \\
\text { MK } \\
10-X\end{array}$ \\
\hline $2008-8$ & 13.10 .2008 & 05.01 .2009 & 84 & 231.6 & & & & 225.0 & 3.0 & & $\mathrm{X}$ & & \\
\hline 2009-1 & 15.10 .2009 & 12.01 .2010 & 89 & 273.5 & 294.0 & 20.5 & 0.2 & 225.0 & 3.5 & $\mathrm{X}$ & & $\mathrm{X}$ & \\
\hline 2009-2 & 15.10 .2009 & 30.12 .2009 & 76 & 267.5 & 310.0 & 42.5 & 0.6 & 235.0 & 5.9 & $\mathrm{X}$ & & $\mathrm{X}$ & \\
\hline $2009-3$ & 16.10 .2009 & 11.01 .2010 & 87 & 268.0 & 300.0 & 32.0 & 0.4 & 228.0 & 3.0 & $\mathrm{X}$ & & $\mathrm{X}$ & \\
\hline $2009-4$ & 16.10 .2009 & 06.01 .2010 & 82 & 269.5 & 370.0 & 100.5 & 1.2 & 230.0 & 3.1 & $\mathrm{X}$ & & $\mathrm{X}$ & \\
\hline $2009-5$ & 17.10 .2009 & 12.01 .2010 & 87 & 397.5 & & & & 276.0 & 0.4 & & $\mathrm{X}$ & & \\
\hline $2009-6$ & 19.10 .2009 & 05.01 .2010 & 78 & 319.5 & 440.0 & 120.5 & 1.5 & 258.0 & 5.6 & & $\mathrm{X}$ & & \\
\hline $2009-8$ & 20.10 .2009 & 20.01 .2010 & 92 & 314.5 & 395.0 & 80.5 & 0.9 & 250.0 & 1.3 & $\mathrm{X}$ & & $\mathrm{X}$ & \\
\hline $2009-9$ & 24.10 .2009 & 10.01 .2010 & 78 & 272.5 & 332.5 & 60.0 & 0.8 & 237.0 & 2.8 & & $\mathrm{X}$ & & \\
\hline $2009-10$ & 25.10 .2009 & 20.01 .2010 & 87 & 321.5 & 370.0 & 48.5 & 0.6 & 249.0 & 2.8 & & $\mathrm{X}$ & & \\
\hline 2009-11 & 25.10 .2009 & 12.01 .2010 & 79 & 300.0 & 375.0 & 75.0 & 0.9 & 219.0 & 2.8 & & $\mathrm{X}$ & & \\
\hline $2010-8$ & 15.10 .2010 & 29.01 .2011 & 106 & 237.5 & 295.0 & 57.5 & 0.5 & 238.0 & 1.1 & $\mathrm{X}$ & & $\mathrm{X}$ & \\
\hline $2010-9$ & 26.10 .2010 & 11.01 .2011 & 77 & 379.5 & 430.0 & 50.5 & 0.7 & 255.0 & 3.4 & $\mathrm{X}$ & & $\mathrm{X}$ & \\
\hline 2010-10 & 16.10 .2010 & 15.01 .2011 & 91 & 214.0 & 321.5 & 107.5 & 1.2 & 231.0 & & $\mathrm{X}$ & & $\mathrm{X}$ & \\
\hline 2010-11 & 18.10 .2010 & 03.01 .2011 & 77 & 314.5 & 392.0 & 77.5 & 1.0 & 260.0 & 3.3 & $\mathrm{X}$ & & $\mathrm{X}$ & \\
\hline $2010-12$ & 16.10 .2010 & & & 427.0 & & & & 280.0 & & $\mathrm{X}$ & & $\mathrm{X}$ & \\
\hline $2010-13$ & 15.10 .2010 & 23.01 .2011 & 100 & 384.8 & 448.0 & 63.2 & 0.6 & 261.0 & 1.6 & $\mathrm{X}$ & & $\mathrm{X}$ & \\
\hline 2010-14 & 18.10 .2010 & 15.01 .2011 & 89 & 283.5 & & & & 236.0 & & $\mathrm{X}$ & & $\mathrm{X}$ & \\
\hline $2010-15$ & 24.10 .2010 & 02.01 .2011 & 70 & 330.5 & & & & 270.0 & 1.2 & $\mathrm{X}$ & $\mathrm{X}$ & $\mathrm{X}$ & $\mathrm{X}$ \\
\hline 2010-18 & 26.10 .2010 & 03.01 .2011 & 69 & 331.0 & 352.5 & 21.5 & 0.3 & 246.0 & 7.5 & & $\mathrm{X}$ & & $\mathrm{X}$ \\
\hline 2010-19 & 31.10 .2010 & 20.01 .2011 & 81 & 395.0 & & & & 266.0 & 1.2 & & $\mathrm{X}$ & & $\mathrm{X}$ \\
\hline $2010-20$ & 01.11 .2010 & 15.01 .2011 & 75 & 342.8 & 481.0 & 138.2 & 1.8 & 255.0 & 5.3 & & $\mathrm{x}$ & & $\mathrm{X}$ \\
\hline $2010-21$ & 18.11 .2010 & 02.01 .2011 & 45 & 376.5 & 425.0 & 48.5 & 1.1 & 218.0 & 1.0 & & $\mathrm{X}$ & & $\mathrm{X}$ \\
\hline 2011-14 & 25.10 .2011 & 26.01 .2012 & 93 & 252.0 & 305.0 & 53.0 & 0.6 & 240.0 & 3.2 & $\mathrm{X}$ & & & $\mathrm{X}$ \\
\hline 2011-16 & 26.10 .2011 & 20.01 .2012 & 86 & 255.0 & 425.0 & 170.0 & 2.0 & 254.0 & 3.0 & & $\mathrm{X}$ & & $\mathrm{X}$ \\
\hline 2011-17 & 26.10 .2011 & 19.01 .2012 & 85 & 225.0 & 329.0 & 104.0 & 1.2 & 225.0 & 1.8 & $\mathrm{X}$ & & & $\mathrm{X}$ \\
\hline 2011-18 & 26.10 .2011 & 17.01 .2012 & 83 & 245.0 & 327.0 & 82.0 & 1.0 & 238.0 & 2.8 & & $\mathrm{X}$ & & $\mathrm{X}$ \\
\hline $2011-21$ & 28.10 .2011 & 31.01 .2012 & 95 & 245.0 & & & & 225.0 & 4.5 & & $\mathrm{X}$ & & $\mathrm{X}$ \\
\hline $2011-22$ & 28.10 .2011 & 20.01 .2012 & 84 & 296.0 & 367.0 & 71.0 & 0.8 & 256.0 & 2.0 & $\mathrm{X}$ & & & $\mathrm{X}$ \\
\hline $2011-26$ & 30.10 .2011 & 26.01 .2012 & 88 & 255.0 & & & & 232.0 & 2.8 & & $\mathrm{X}$ & & $\mathrm{X}$ \\
\hline 2011-27 & 30.10 .2011 & 16.01 .2012 & 78 & 236.0 & 307.0 & 71.0 & 0.9 & 235.0 & 8.1 & & $\mathrm{X}$ & & $\mathrm{X}$ \\
\hline 2011-28 & 30.10 .2011 & 14.01 .2012 & 76 & 249.0 & 328.0 & 79.0 & 1.0 & 240.0 & 3.6 & & $\mathrm{X}$ & & $\mathrm{X}$ \\
\hline $2011-29$ & 03.11 .2011 & & & 262.0 & & & & 230.0 & & & $\mathrm{X}$ & & $\mathrm{X}$ \\
\hline 2011-30 & 27.10 .2011 & & & 300.0 & & & & 240.0 & & $\mathrm{X}$ & & & $\mathrm{X}$ \\
\hline Mean & & & 83 & 296.2 & 366.4 & 75.4 & 0.9 & 243.0 & 3.2 & & & & \\
\hline SD & & & 11 & 56.5 & 56.3 & 35.9 & 0.4 & 16.4 & 1.9 & & & & \\
\hline
\end{tabular}

dives were performed during day, night and twilight, respectively. The mean dive duration and mean diving depth were $21.4 \pm 4.8 \mathrm{~min}$ and $519.2 \pm$ $208.3 \mathrm{~m}$ for day; $16.7 \pm 4.2 \mathrm{~min}$ and $384.4 \pm 199.2 \mathrm{~m}$ for night; and $18.6 \pm 3.8 \mathrm{~min}$ and $391.5 \pm 196.3 \mathrm{~m}$ for twilight, respectively. The bottom duration of a dive was found to increase with dive duration but to decrease with increasing diving depth (Table 2). Dive duration increased with the number of days elapsed since departure from land. $T_{200}$ exercised a different effect between day and night. During the day, for a given diving depth, seals increased their dive duration with increasing $T_{200}$ while a negative effect was found at night and no relationship for twilight (Table 3).
The vast majority of dives $(88.8 \%)$ were concentrated in water masses having a $T_{200}$ encompassed between the AD and the SAF (Fig. 3). However, it is worth noting that $49.0 \%$ of the dives were distributed within water masses with a $T_{200}$ ranging between 1 and $3^{\circ} \mathrm{C}$, revealing that while foraging within the ACC zone, post-breeding female SES favoured water masses located primarily south of the PF. Approximately one-third $(35.5 \%)$ of the dives were located in water masses encompassed between the PF and SAF. Only $6.0 \%$ of the dives were between the SAF and STF, with just $3.5 \%$ just north of the STF and $1.8 \%$ south of the AD (Fig. 3).

Diving depth increased with increasing $L_{0}, L_{150} / L_{0}$, as well as $T_{200}$ both during day and night. Daytime 

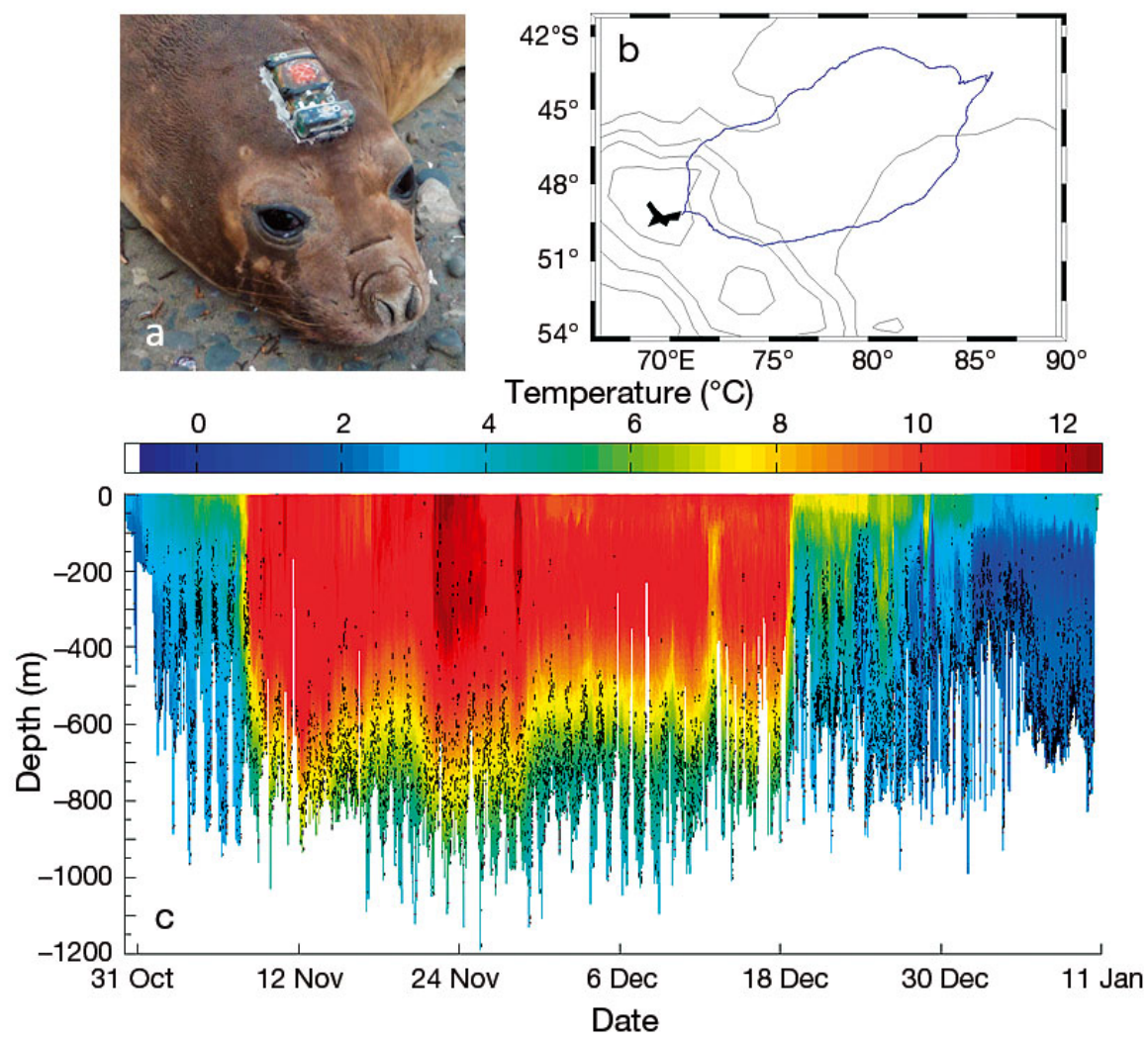

Fig. 2. An example of one female southern elephant seal (a) equipped with a SPLASH 10 tag combined with a head-mounted accelerometer enabling the reconstruction of the (b) seal track as well as (c) the distribution of prey encounter events (PEEs; black circles) according to depth and temperature monitored along the track of the animal

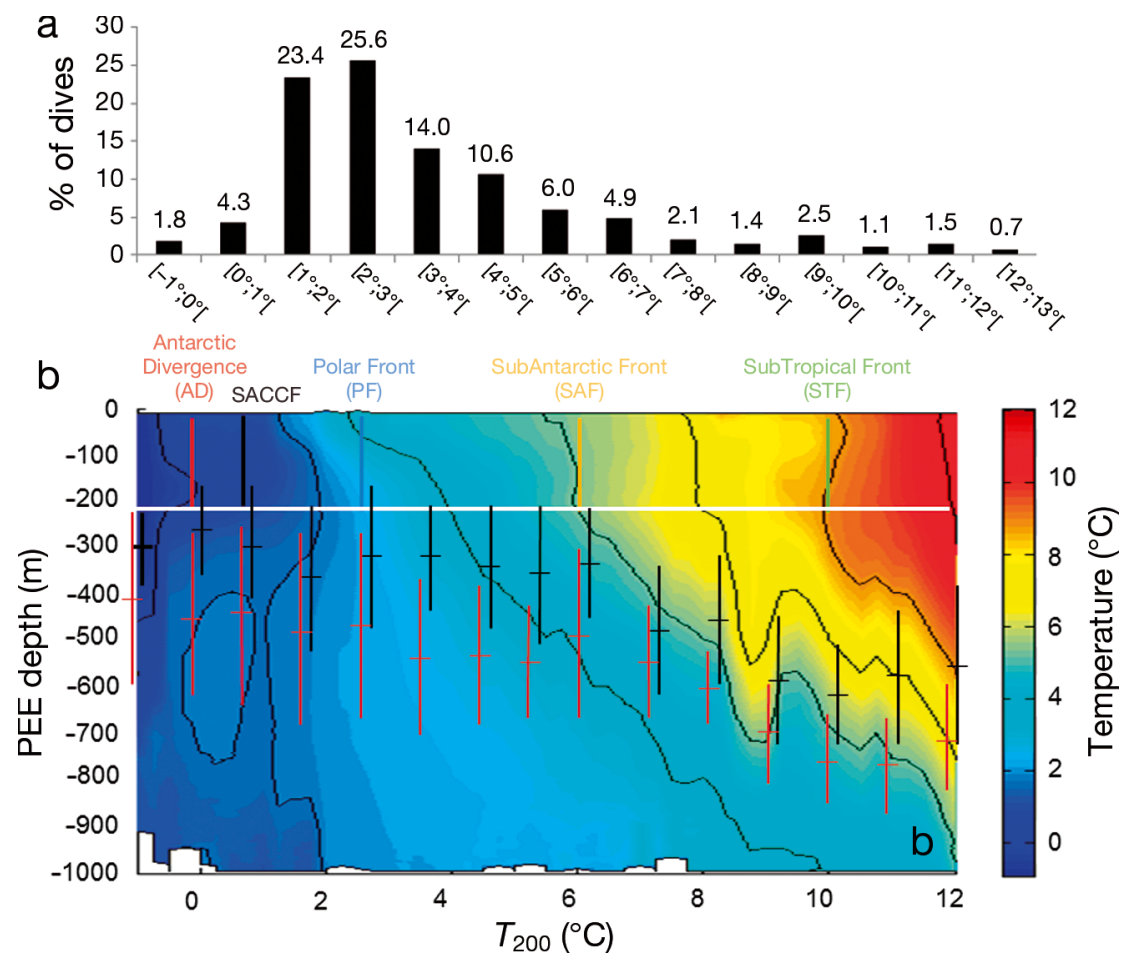

PEE depth increased with increasing $L_{0}, L_{150} / L_{0}$ and $T_{200}$, while no effect of $T_{200}$ was detected at night (Table 4 ).

The difference in mean diving depth between day and night varied more to the south than to the north of the SAF (Fig. 4). Consequently, there was less difference between the depths of day and night dives as the individuals headed towards the STF (Fig. 4). This was particularly noticeable for $T_{200}$ exceeding $7^{\circ} \mathrm{C}$ (i.e. north of the SAF), for which PEE depth tended to increase rapidly with increasing $T_{200}$, during both the day and the night (Fig. 4). Indeed, mean diving depth increased significantly with increasing $T_{200}$ during the day but not at night south of the SAF $\left(T_{200}\right.$ $<7^{\circ} \mathrm{C}$ ). The same significant effect of $T_{200}$ on diving depth was found north of the SAF $\left(T_{200}>7^{\circ} \mathrm{C}\right.$ i Table 5), but during both day and night. Furthermore, diving depth was positively related to increasing $L_{0}$ north and south of the SAF during both day and night. In addition, diving depth was also related to $L_{150} / L_{0}$ during day and night south of the SAF and only at night north of the SAF (Table 5).

\section{Variation in foraging success}

For the 12 SES equipped with headmounted accelerometers, the PEE

Fig. 3. A temperature transect reconstructed according to the temperature profiles ranked according to temperature at $200 \mathrm{~m}$ $\left(T_{200}\right)$. (a) The percentage of dives for the 29 southern elephant seals taking place for each $1^{\circ} \mathrm{C}$ temperature class. Number on top of bar is the \% of dives observed for each class. (b) The main frontal structures are located along this transect according to their $T_{200}$ signature (white line, see Fig. 1 for details). Mean $( \pm \mathrm{SD})$ prey encounter event (PEE) depth during day (red) and night (black) obtained from the 12 seals equipped with head-mounted accelerometers for each $1^{\circ} \mathrm{C}$ temperature class overlaid on the temperature transect constructed from the data collected by the 29 seals. SACCF: Southern Antarctic Circumpolar Current Front 
events were extracted along the track (time) and related to the corresponding pressure and $T_{200}$ measurements (see Fig. 3). A total of 204045 PEEs were detected, with $63.3,26.1$ and $10.6 \%$ occurring during day, night and twilight, respectively. A total of 73, 14 and $13 \%$ of the PEEs took place at the bottom, during the descent and during the ascent of the dive, respectively. When considering the PEE per unit of time spent diving or spent at the bottom of the dive, seals were found to be significantly more efficient during twilight compared with at night (dive: $W=7075193$, $\mathrm{p}<0.001$; bottom: $W=7680996, \mathrm{p}<0.001)$ or during the day (dive: $W=44313536, \mathrm{p}<0.001$; bottom: $W=$

Table 2. Bottom duration according to dive duration and diving depth. ${ }^{* * *} \mathrm{p}<0.001$

\begin{tabular}{|llrr|}
\hline Model & Parameter & Estimate & \multicolumn{1}{c|}{$t$} \\
\hline Bottom duration & Dive duration & 307.65 & $858.06^{* * *}$ \\
& Diving depth & -271.94 & $-800.29^{* * *}$ \\
\hline
\end{tabular}

Table 3. Dive duration of female southern elephant seals according to $200 \mathrm{~m}$ temperature $\left(T_{200}\right)$, diving depth and number of days elapsed since departure for day, night and twilight. ${ }^{* *} p<0.01{ }^{* * *} p<0.001$

\begin{tabular}{|c|c|c|c|c|c|c|c|}
\hline \multirow[t]{2}{*}{ Model } & \multirow{2}{*}{$\begin{array}{l}\text { Para- } \\
\text { meter }\end{array}$} & \multicolumn{2}{|l|}{ _ Day } & \multicolumn{2}{|c|}{ — Night } & \multicolumn{2}{|c|}{${ }_{-}$Twilight } \\
\hline & & Estimate & $t$ & Estimate & $t$ & Estimate & $t$ \\
\hline \multirow{3}{*}{$\begin{array}{l}\text { Dive } \\
\text { duration }\end{array}$} & $T_{200}$ & 18.73 & $7.31^{* *}$ & -31.42 & $-7.30^{* *}$ & - & $\mathrm{ns}$ \\
\hline & $\begin{array}{l}\text { Diving } \\
\text { depth }\end{array}$ & 35.01 & $32.27^{* * *}$ & 40.71 & $26.53^{* * *}$ & 45.13 & $15.67^{* * *}$ \\
\hline & $\begin{array}{l}\text { Days since } \\
\text { departure }\end{array}$ & 67.49 & $31.62^{* * *}$ & 61.89 & $24.75^{* * *}$ & 63.84 & $14.50^{* * *}$ \\
\hline
\end{tabular}

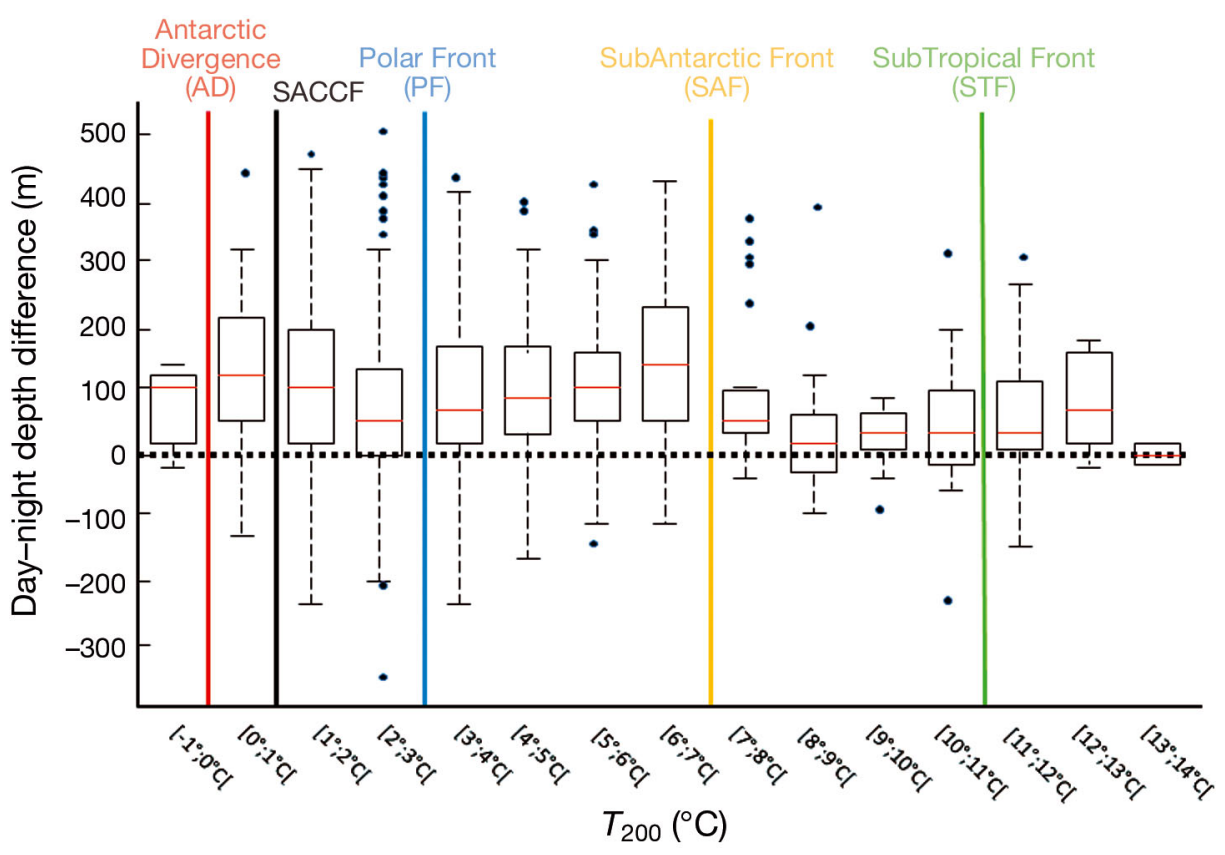

$49752533, p<0.001$ ), and they were also more efficient during the night compared with during the day (dive: $W=19339935, \mathrm{p}<0.001$; bottom: $W=$ 19852 229, p < 0.001; see Fig. 5).

Drift dives, which are considered essentially as non-foraging dives and function as periods of recovery (Crocker et al. 1997), had very few prey captures $(0.39 \pm 1.93$ PEEs per drift dive, $\mathrm{n}=501)$. Excluding these dives, an average of $8.2 \pm 6.6$ PEEs were recorded per dive $(\mathrm{n}=25761)$. The mean PEE depth was $467 \pm 211,304 \pm 138$ and $308 \pm 151 \mathrm{~m}$ for day, night and twilight, respectively.

A visual examination of PEE depth distribution reveals that it varied between day and night and according to $T_{200}$ (Fig. 6). For $T_{200}$ ranging between 0 and $7^{\circ} \mathrm{C}$, the PEE tended to exhibit a bimodal distribution both during day and night. However, both modes are shallower at night compared with the daylight hours. In contrast, for $T_{200}$ higher than $7^{\circ} \mathrm{C}$, individuals were capturing prey much deeper both at night and during the day. Furthermore, PEE depth distribution was unimodal and very deep (500-800 m), which tended to be slightly shallower at night compared with during daylight hours.

The number of PEEs for a complete diving event was negatively related to both dive duration and diving depth regardless of the time period (day, night or twilight). The number of PEEs at the bottom of the dive was negatively related to diving depth during both day and
Fig. 4. Box plot of the mean depth differences between day and night dive according to each $1^{\circ} \mathrm{C}$ temperature at $200 \mathrm{~m}$ $\left(T_{200}\right)$ class. Horizontal lines represent the median, the box represents the 0.75 to 0.25 quartiles, and whiskers represent 1.5 times the interquartile range (IQR). Small circles represent outliers (i.e. values exceeding 1.5 times IQR). SACCF: Southern Antarctic Circumpolar Current Front. 
Table 4. Variation in diving depth and prey encounter event (PEE) depth of female southern elephant seals according to surface light $\left(L_{0}\right)$, the percentage of surface light reaching $150 \mathrm{~m}\left(L_{150} / L_{0}\right)$ and $200 \mathrm{~m}$ temperature $\left(T_{200}\right)$, for day and night. ${ }^{* *} \mathrm{p}<0.001$

\begin{tabular}{|c|c|c|c|c|c|}
\hline \multirow{2}{*}{ Model } & \multirow{2}{*}{$\begin{array}{l}\text { Para- } \\
\text { meter }\end{array}$} & \multicolumn{2}{|c|}{ — Day $ـ$} & \multicolumn{2}{|c|}{ Night } \\
\hline & & Estimate & $t$ & Estimate & $t$ \\
\hline \multirow{3}{*}{$\begin{array}{l}\text { Diving } \\
\text { depth }\end{array}$} & $L_{0}$ & 36.81 & $25.66^{* * *}$ & 25.57 & $10.54^{* * *}$ \\
\hline & $L_{150} / L_{0}$ & 30.80 & $19.64^{* * *}$ & 32.25 & $15.97^{* * *}$ \\
\hline & $T_{200}$ & 32.83 & $16.81^{* * *}$ & 29.98 & $11.68^{* * *}$ \\
\hline PEE & $L_{0}$ & 36.76 & $28.32^{* * *}$ & - & ns \\
\hline \multirow[t]{2}{*}{ depth } & $L_{150} / L_{0}$ & 38.94 & $26.55^{* * *}$ & 16.16 & $9.87^{* * *}$ \\
\hline & $T_{200}$ & 37.49 & $18.90^{* * *}$ & 31.43 & $14.85^{* * *}$ \\
\hline
\end{tabular}
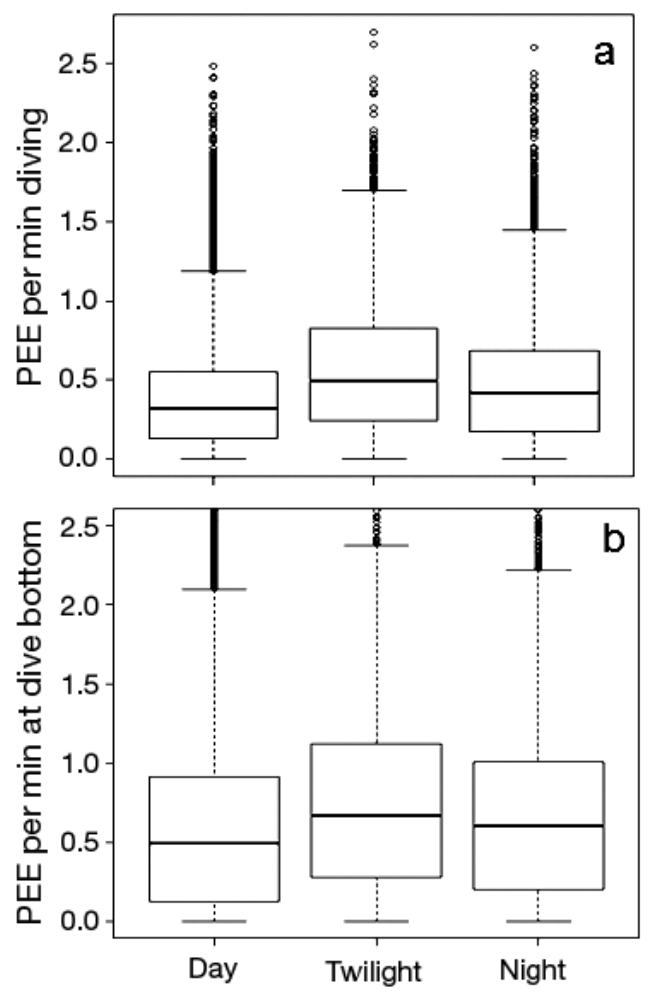

Fig. 5. (a) Box plot of prey encounter events (PEE) per minute spent diving for day, night and twilight periods. (b) Box plot of PEE per minute spent at the bottom of the dive for day, night and twilight periods (see text for details). See Fig. 4 for further details night, but was positively related to the duration of the bottom phase of the dive during day and twilight periods (no effect was detected at night). Furthermore, PEEs for a complete dive and at the bottom of the dive were negatively related to the $L_{150} / L_{0}$, with no effect of $L_{0}$, during the day but positively related to both $L_{0}$ and $L_{150} / L_{0}$ during night and twilight (Table 6).

PEEs per unit of time spent diving or at the bottom of the dive were also found to vary significantly according to the water masses visited by the SES. Compared to what is expected from an even distribution of PEE rate according to $T_{200}$, individuals were performing more PEEs per unit of time for the following $T_{200}$ water classes: $-1^{\circ} \mathrm{C}, 0^{\circ} \mathrm{C}, 2^{\circ} \mathrm{C}, 3^{\circ} \mathrm{C}, 4^{\circ} \mathrm{C}, 5^{\circ} \mathrm{C}$, $6^{\circ} \mathrm{C}$ and $7^{\circ} \mathrm{C}$ (Fig. 7). However, no relationship was found between either the absolute or the daily mass gain and the mean $T_{200}$ of the water masses visited by the seal $\left(\mathrm{r}^{2}<0.01, \mathrm{p}>0.9\right.$ in both cases).

\section{DISCUSSION}

The results of the present study clearly demonstrate that during late spring and early summer the diving behaviour and foraging success of SES females were profoundly affected by the physical properties of the water masses visited. Indeed, these results show that at depth, water temperature, surface light level and the percentage of surface light reaching $150 \mathrm{~m}$ (used as an indicator of phytoplankton concentration) influence the SES foraging during day, night and twilight periods. Correspondingly, these data reveal the vertical distribution of the SES prey guild in relation to environmental variables.

Firstly, SES females dive deeper as $T_{200}$ increases, indicating that the vertical accessibility of the prey decreases from the AD to subtropical waters. This finding is consistent with previous studies indicating that SES are diving deeper in warmer waters (Biuw et al. 2007, McIntyre et al. 2011b). Interestingly, when controlling for $T_{200}$, the deeper the SES dive,

Table 5. Variation in diving depth of female southern elephant seals according to surface light $\left(L_{0}\right)$, the percentage of surface light reaching $150 \mathrm{~m}\left(L_{150} / L_{0}\right)$ and $200 \mathrm{~m}$ temperature $\left(T_{200}\right)$ south and north of the Subantarctic Front for day and night. ${ }^{*} \mathrm{p}<$ $0.05{ }^{* *} \mathrm{p}<0.01 ;{ }^{* * *} \mathrm{p}<0.001 ;$ ns: not significant

\begin{tabular}{|c|c|c|c|c|c|c|c|c|c|}
\hline \multirow[t]{3}{*}{ Model } & \multirow[t]{3}{*}{ Parameter } & \multicolumn{4}{|c|}{$-T_{200}<7^{\circ} \mathrm{C}$} & \multicolumn{4}{|c|}{$T_{200}>7^{\circ} \mathrm{C}$} \\
\hline & & $\bar{D}$ & $\mathrm{y}-$ & $\overline{\mathrm{Ni}}$ & ht - & $\bar{D}$ & $\longrightarrow$ & $\mathrm{Nig}$ & 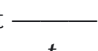 \\
\hline & & Estimate & $t$ & Estimate & $t$ & Estimate & $t$ & Estimate & $t$ \\
\hline \multirow[t]{3}{*}{ Diving depth } & $L_{0}$ & 38.69 & $25.51^{* * *}$ & 24.97 & $8.67^{* *}$ & 24.41 & $6.09^{* *}$ & 23.07 & $8.27^{* *}$ \\
\hline & $L_{150} / L_{0}$ & 33.58 & $20.73^{* * *}$ & 29.05 & $14.65^{* * *}$ & - & ns & 29.45 & $7.33^{* *}$ \\
\hline & $T_{200}$ & 18.64 & $10.46^{* * *}$ & - & ns & 233.5 & $3.59^{*}$ & 21.02 & $4.54^{* *}$ \\
\hline
\end{tabular}



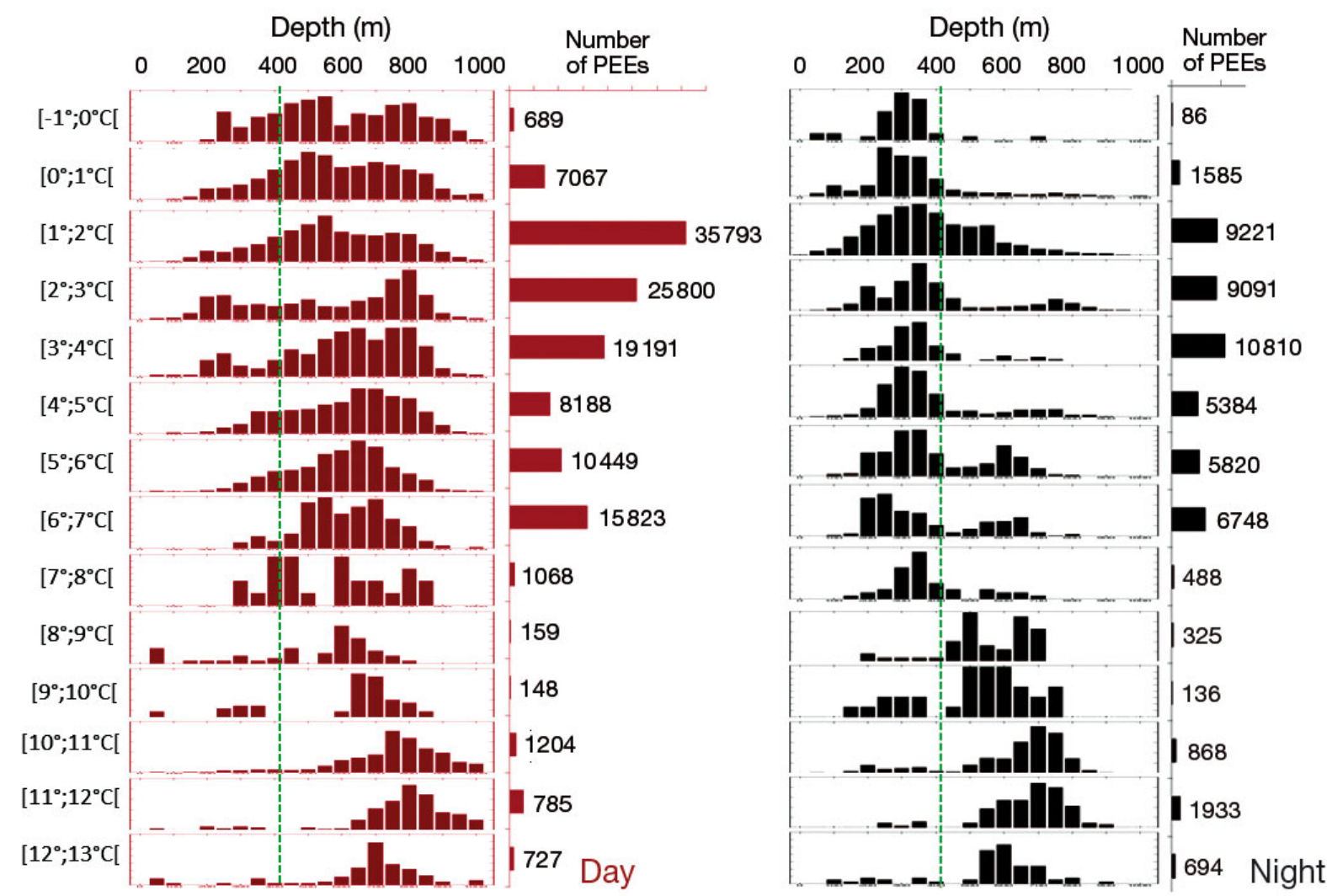

Fig. 6. Depth distribution of prey encounter events (PEEs) according to $50 \mathrm{~m}$ depth class during day (red) and night (black) according to each $1^{\circ} \mathrm{C}$ temperature at $200 \mathrm{~m}\left(T_{200}\right)$ class. The number of PEEs during day and night for each $T_{200}$ class is indicated

the fewer prey they capture for a given bottom duration, suggesting a general decrease in prey density with increasing depth (Table 6). For waters with a $T_{200}$ warmer than $7^{\circ} \mathrm{C}$, a significant decrease in PEEs per unit of time spent diving or at the bottom of the dive was found, suggesting that lower prey densities and at greater depth were found north of the SAF.
Furthermore, as SES dive deeper, swimming costs associated with the bottom-surface transit increase and, as a consequence, the amount of time the seal is able to allocate to foraging at the bottom of the dive (i.e. the efficient foraging part of the dive) decreases with increasing diving depth. Furthermore, when considering a complete dive, and contrary to our

Table 6. Variation of the number of prey encounter events (PEE) by female southern elephant seals during the dive and at the bottom of the dive scale according to dive metrics and environmental conditions (surface light $\left[L_{0}\right]$, the percentage of surface

light reaching $150 \mathrm{~m}\left[L_{150} / L_{0}\right]$ and $200 \mathrm{~m}$ temperature $\left.\left[T_{200}\right]\right) .{ }^{*} \mathrm{p}<0.05_{;}{ }^{* *} \mathrm{p}<0.01 ;{ }^{* * *} \mathrm{p}<0.001 ;$ ns: not significant

\begin{tabular}{|c|c|c|c|c|c|c|c|}
\hline \multirow[t]{2}{*}{ Model } & \multirow[t]{2}{*}{ Parameter } & \multicolumn{2}{|c|}{$\longrightarrow$ Day $\longrightarrow$} & \multicolumn{2}{|c|}{- Night -} & \multicolumn{2}{|c|}{ — Twilight } \\
\hline & & Estimate & $t$ & Estimate & $t$ & Estimate & $t$ \\
\hline \multirow[t]{5}{*}{ PEE dive } & $T_{200}$ & - & ns & - & ns & - & $\mathrm{ns}$ \\
\hline & $L_{0}$ & - & ns & 0.220 & $11.75^{* * *}$ & 0.090 & $6.05^{* *}$ \\
\hline & $L_{150} / L_{0}$ & -0.110 & $-10.96^{* * *}$ & 0.210 & $10.42^{* * *}$ & 0.052 & $2.65^{*}$ \\
\hline & Dive duration & -0.070 & $-7.79^{* *}$ & -0.171 & $-12.21^{* * *}$ & -0.600 & $-3.31^{* *}$ \\
\hline & Diving depth & -0.150 & $-20.33^{* * *}$ & -0.029 & $-2.67^{*}$ & -0.210 & $-11.55^{* * *}$ \\
\hline \multirow[t]{5}{*}{ PEE bottom } & $T_{200}$ & - & ns & - & ns & - & ns \\
\hline & $L_{0}$ & - & $\mathrm{ns}$ & 0.289 & $13.69^{* * *}$ & 0.114 & $6.82^{* *}$ \\
\hline & $L_{150} / L_{0}$ & -0.080 & $-6.56^{* *}$ & 0.280 & $12.87^{* * *}$ & 0.115 & $5.47^{* *}$ \\
\hline & Bottom duration & 0.079 & $8.06^{* *}$ & - & ns & 0.060 & $2.66^{*}$ \\
\hline & Diving depth & -0.38 & $-38.60^{* * *}$ & -0.360 & $-25.97^{* * *}$ & -0.51 & $-19.61^{* * *}$ \\
\hline
\end{tabular}



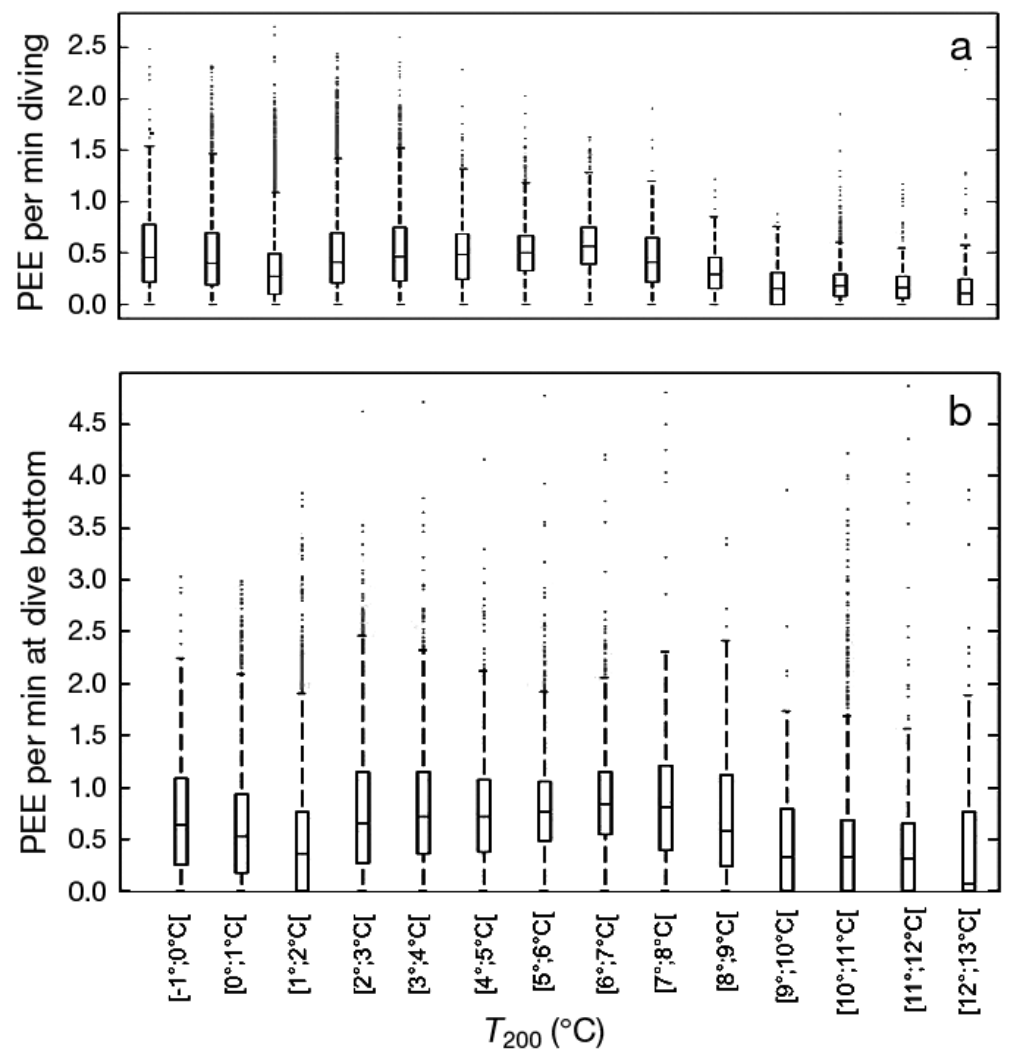

Fig. 7. (b) Box plot of prey encounter events (PEEs) per minute spent diving according to each $1^{\circ} \mathrm{C}$ temperature at $200 \mathrm{~m}\left(T_{200}\right)$ class. (b) Box plot of PEEs per minute spent at the bottom of the dive according to each $1^{\circ} \mathrm{C} T_{200}$ class. See Fig. 4 for further details

expectation, the number of PEEs decreases with increasing dive duration, suggesting that successful foraging dives were energetically more costly (i.e. higher swimming effort) than unsuccessful ones, forcing the seals to come back earlier to the surface. An alternative and non-exclusive hypothesis is that elephant seals modify their dive duration by changing the ascent or descent behaviour (i.e. by descending and ascending more rapidly to the surface) when they encounter high-quality prey patches, as reported in king penguins (Hanuise et al. 2013). Furthermore, when controlling for diving depth, the number of PEEs at the bottom of the dive increases with bottom duration during the day and twilight periods, but not at night, indicating that seals adjust the amount of time allocated to the efficient phase of their dive (bottom) in relation to prey density when generally diving deeper during the day and twilight compared with shallower night dives. Future studies should investigate how these observed variations match with the predictions of the optimal diving theory (Carbone \& Houston 1994).
PEEs both during the whole dive and at the bottom of the dive were not related to $T_{200}$, suggesting that $T_{200}$ has a general effect on prey vertical accessibility but not on foraging success when controlling for dive duration and diving depth. Correspondingly, in the present study, very few seals foraged in water with $T_{200}$ exceeding $7^{\circ} \mathrm{C}$ (i.e. north of the SAF). Such a behavioural change associated with the SAF is consistent with previous studies indicating that the SAF represents an important biogeographic boundary regarding the latitudinal distribution of warm-water zooplankton (Ansorge et al. 1999) and myctophid species (Koubbi 1993, Koubbi et al. 2011), as well as top marine predators such as seabirds (Bost et al. 2009).

Individuals were found to exhibit lower PEE rates in water masses with $T_{200}$ ranging between 1 and $2^{\circ} \mathrm{C}$, corresponding to the zone encompassed between the PF and the SACCF. This is consistent with the finding of Biuw et al. (2007) that SES exhibited negative changes in body condition while migrating between the $\mathrm{PF}$ and the SACCF. In the Indian Ocean sector, this zone broadens latitudinally in the Kerguelen region (Orsi et al. 1995) and this sector seems to represent a large region of unfavourable foraging conditions for SES. Despite our results supporting previous findings that dive capacity increases throughout the duration of the foraging trips (Bennett et al. 2001, Hassrick et al. 2010, McIntyre et al. 2011b), both $T_{200}$ and diving depth were also found to influence dive duration in the present study.

For $T_{200}$ lower than $7^{\circ} \mathrm{C}_{,} T_{200}, L_{0}$ and $L_{150} / L_{0}$ had a positive effect on the diving depth of SES during the day. No effect of $T_{200}$ was found at night (Table 5). As $L_{0}$ is mostly related to both cloud cover and sun angle during the day and cloud cover and moon light at night, the present study emphasises the critical effect of light, mediated through its effect on the distribution of SES prey, on the diving behaviour of SES both during the day, as previously found by Jaud et al. (2012), and at night.

Light level at depth depends on the amount of light reaching the surface of the ocean and the intensity of light attenuation within the water column. In oceanic waters, phytoplankton concentra- 
tion is a critical factor controlling most of the surface light attenuation within the water column and, therefore, light levels below the euphotic layer (Morel 1988). Light level at $150 \mathrm{~m}$, combining the effect of surface light and light attenuation within the first $150 \mathrm{~m}$ of the water column, has been found to explain nearly $70 \%$ of the variation in the daylight diving depth of seals foraging between the PF and the SAF (Jaud et al. 2012). In the present study, with a larger data set we were able to show that SES also modified their diving behaviour at night according to both $L_{0}$ and $L_{150} / L_{0}$, diving deeper when more light was available at the surface and when that light was less attenuated within the water column, suggesting that in clearer waters with lower phytoplankton concentrations seals had to dive deeper to reach their prey. This finding was consistent with the results obtained by Dragon et al. (2010) showing that the diving depth of SES was negatively related to remotely sensed surface chlorophyll a concentration.

The fact that light levels at the surface had an effect on the diving depth of SES at night suggests that variation of moonlight intensity in relation to moon cycle controls the vertical extent of the nycthemeral migration of SES prey and, therefore, their vertical accessibility, with prey items migrating closer to the ocean surface during the darkest nights. A similar effect of moonlight on diving behaviour has previously been observed in Galapagos fur seals Arctocephalus galapagoensis (Horning \& Trillmich 1999) and northern fur seals Callorhinus ursinus (Lea et al. 2010). Several studies have shown that the extent of the vertical, nocturnal migration of zooplankton is related to changes in $L_{0}$ and water transparency, and that $L_{0}$ is dependent on the moon phase and/or cloud cover (Rudstam et al. 1989, Dodson 1990). Indeed, light is an essential factor for the vertical distribution of a broad range of mesopelagic marine animals, ranging from zooplankton (Liu et al. 2003) to fish (Batty et al. 1990), which distribute themselves according to precise light isolines, with threshold light intensity ('barrier isolume') found to initiate an avoidance reaction by these organisms (Boden \& Kampa 1967, Kampa 1976, Gal et al. 1999, Cotté \& Simard 2005).

The strong influence of light on the diving behaviour of SES leads us to hypothesise that the large variability in diving depth observed in water for a given $T_{200}$ south of the SAF is likely to be explained by high variability in the amount of light available at depth in response to variations in cloud cover, phytoplankton concentration and sunlight or moonlight.
Therefore, while the change in phytoplankton concentration in summer is likely to have an effect on the overall SO productivity and the amount of prey available to SES several months later, it also exerts substantial influence on the vertical accessibility of SES prey. This has direct consequences on the foraging efficiency of these predators, as the deeper they dive, the less efficient (in terms of PEE events per unit of time) they are.

Interestingly, the influence of light on PEEs differed temporally. Surface light $\left(L_{0}\right)$ had no effect on PEEs during the day, but had a positive effect during the night and twilight periods (see Table 6). Similarly, $L_{150} / L_{0}$ had a negative effect on PEEs during the day but a positive effect at night and twilight. $L_{150} / L_{0}$ is related to the concentration of particles (including phytoplankton) present in the water (Jaud et al. 2012). Therefore, the negative relationship found between $L_{150} / L_{0}$ and PEEs would suggest that SES are more successful during the day in areas where higher concentration of particles such as phytoplankton but also possibly zooplankton are encountered. In contrast, both $L_{0}$ and $L_{150} / L_{0}$ were found to have a positive effect on PEEs during twilight and at night. This suggests that light level within the water column could indirectly impact the foraging success of SES, potentially by influencing the distribution, availability and/or detectability of prey on clear nights and in clear waters.

SES dive generally to shallower depths at night than during daylight hours (Hindell et al. 1991, Biuw et al. 2007); in some instances they have been observed to dive to greater depths at night compared with the day, suggesting that they might be foraging on different prey resources on those occasions (McIntyre et al. 2011a). Consistent with Biuw et al. (2007), the greatest differences between day and night diving depths observed in the present study were between the SAF and the SACCF (i.e. the ACC zone). A noticeable exception was in both Antarctic waters and waters north of the SAF, where the diurnal variation diminished. Reduced differences in diving depth between day and night were observed for high and low $T_{200}$. However, the factors responsible for these differences between Antarctic and subtropical waters are likely to be different. For the subantarctic-subtropical zone, the contribution of $L_{0}$ and $L_{150} / L_{0}$ to the variation in diving depth was found to be lower to the north than to the south of the SAF. We interpret this result as the consequence of the deepening of SES females dives in search of prey found in deeper, colder waters. The $8^{\circ} \mathrm{C}$ isotherm appears to represent the upper limit of the vertical distribution 
of most of the SES's prey (see Figs. 2, 3) and the diving depth of SES deepens with this isotherm from the SAF to the STF (Fig. 3). Indeed, as light levels decrease exponentially with depth, the influence of light levels should decrease north of the SAF at all times due to the increased diving depth required to reach the SES's prey; as a consequence, the diurnal differences in dive depth should decrease, as observed. A reduced diurnal difference in the diving depths of SES was also observed in Antarctic waters. This is consistent with a previous report (Biuw et al. 2007) that interpreted this as indicating animals foraging benthically on the Antarctic Shelf. However, all SES females in our study foraged in oceanic waters associated with the $\mathrm{AD}$, well off the Antarctic Shelf. Therefore, the reduced diurnal difference in diving depth (Fig. 4) suggests that SES females were feeding on prey remaining close to the surface during daylight hours.

The SO is characterised by broad concentric bands of water masses around the Antarctic continent, with each zone maintaining its unique physical properties (e.g. Orsi et al. 1995, Belkin \& Gordon 1996). This has 2 implications. Firstly, the concentric nature of the current and water masses of the SO ensures circumpolar continuity of its ecosystems and zooplankton and fish species (Baker 1954). Therefore, our findings regarding the vertical distribution of SES prey could be extrapolated to other parts of the SO. Secondly, the $T_{200}$ gradient used in our study largely reflects the latitudinal structuring of the SO from subtropical to Antarctic waters.

The first assumption of our study is that female SES diet is dominated by myctophid fish. Recent studies suggest that myctophids are likely to represent a major proportion of the SES female diet (Cherel et al. 2008, Bailleul et al. 2010) and 3 of the dominant myctophid species in the SO (Electrona antarctica, E. calsbergi and Gymnoscopelus nicholsi) have previously been found in stomach contents of SES (Slip 1995, Daneri \& Carlini 2002). Furthermore, a recent study using a head-mounted camera on northern elephant seals (Naito et al. 2013) identified 2 small mesopelagic fishes as prey items, a myctophid and a bathypelagid, suggesting that elephant seals, despite their large size, are feeding on abundant but small prey items. Indeed, myctophid fish are a high-calorific prey $\left(9.3 \mathrm{~kJ} \mathrm{~g}^{-1}\right.$ wet mass) when compared with icefish (5.4 $\mathrm{kJ} \mathrm{g}^{-1}$ wet mass) and prey items such as squid $\left(1.7-4.5 \mathrm{~kJ} \mathrm{~g}^{-1}\right.$ wet mass; Lea et al. 2002a,b). However, we acknowledge that other prey items such as squids are also likely consumed by SES.
The second assumption of our study is that a PEE provides a robust proxy for actual prey encounters. According to the calculated mean catch rate of 8.2 prey items per dive, we estimate that on average a SES female performing approximately 66 dives per day will catch approximately 540 prey items daily. Assuming that Electrona calsbergi, E. antarctica, Gymnoscopelus nicholsi and G. piabilis represent the major prey items within the ACC zone and that their mass generally ranges between $9 \mathrm{~g}$ (Electrona calsbergi, E. antarctica) and $30 \mathrm{~g}$ (G. nicholsi, G. piabilis; C. A. Bost \& Y. Cherel pers. comm.), we estimate that a range of $4.8-16.1 \mathrm{~kg}$ of fish are ingested daily per seal. These values are not inconsistent with the daily mass gains (mean $0.9 \pm 0.4 \mathrm{~kg}$, range: $0.2-2 \mathrm{~kg}$ ) observed in the post-breeding females in our study using a mean $10 \%$ energy transfer efficiency to body mass growth (see Ashwell Erickson \& Elsner 1981, Rosen \& Trites 1999, Jeanniard du Dot et al. 2008). These estimates are consistent with those based on calculations using at-sea field metabolic rates and photographs obtained by head-mounted cameras (Naito et al. 2013), revealing that northern elephant seal females feed on small mesopelagic prey (10$20 \mathrm{~g}$ ), catching 430 to 860 prey items and an estimated ingested mass ranging between 4.3 and $17.2 \mathrm{~kg}$ of prey daily.

The SO mesopelagic ichthyofauna is dominated by myctophids (Kock 1992), with approximately 35 species (Hulley 1990) and a crude estimated biomass ranging between 70 and 340 million tonnes (Lubimova et al. 1987, Sabourenkov 1991). Previous studies suggest that temperature, light and oxygen content of the water are key environmental factors controlling their distribution (Hulley \& Lutjeharms 1995).

Four species of myctophids contribute the bulk of the SO fish biomass: Krefftichthys anderssoni, Electrona antarctica, E. carlsbergi and Gymnoscopelus nicholsi (Sabourenkov 1991). Despite their ecological significance and considerable biomass, remarkably little is known about the basic biology of myctophids (Collins et al. 2008). While they are known to perform daily vertical migrations in the water column, remaining at deep depths during the day and feeding in shallower depths at night (Gjosaeter \& Kawaguchi 1980), there is a major lack of knowledge regarding myctophid habitats and environmental factors controlling their distribution (Gjosaeter \& Kawaguchi 1980, Catul et al. 2011). Assuming that myctophids represent the main component of SES female diet, the fine-scale monitoring of SES foraging behaviour according to environmental factors provides indirect 
information on the myctophid vertical distribution in relation to temperature and light conditions along a north-south latitudinal gradient.

Our results suggest that SES may target different communities of myctophids at different depths north of the SAF. Indeed, as part of the ICHTYOKER transect run between Kerguelen and St. Paul Island, data from trawls at night to depths ranging between 0 and $330 \mathrm{~m}$ in waters with a temperature range of $11-17^{\circ} \mathrm{C}$ revealed a myctophid community dominated by $\mathrm{Sym}$ bolophorus barnardi, Lampanyctus australis, Electrona paucirastra and Lampichthys procerus (G. Duhamel, P. Prouvost, J. Boutain unpubl. data). These fish species were more abundant in the northern vicinity of the STF. Therefore, the fact that SES dive to deeper depths to reach water temperatures lower than $8^{\circ} \mathrm{C}$ suggests that they target a different assemblage of myctophids. This community is likely to be dominated by Electrona calsbergi, E. subaspera, Gymonoscopelus piabilis, G. fraseri and G. bolini, and this mycthophid community distribution deepens with increasing temperature north of the SAF (Hulley 1981).

As mentioned earlier, a reduced diurnal difference in the diving depths of SES was also detected in Antarctic waters. This behaviour was also detected on very few occasions between the SACCF and the PF. In Antarctic waters, Electrona carlsbergi, a schooling species (Zasel'sliy et al. 1985), is commonly encountered close to the surface during the day (Hulley 1986, Fielding et al. 2012). Electrona antarctica, a non-schooling species, which is slightly larger than E. carlsbergi, is also found in SES stomach contents and may also represent an important prey item, along with E. carslbergi.

The difference in schooling behaviour of Electrona species might influence the foraging strategy of SES. Indeed, 3-dimensional reconstruction of dive tracks reveals that the sinuosity of the path at the bottom of the dive increases with the number of PEEs. Individuals exhibit an area-restricted search behaviour at the bottom of their dive and for several consecutive dives when large numbers of PEEs occur (C. G., J. V.-G., Y. L., J. Jouma'a unpubl. data), suggesting that SES are targeting schooling resources in these dives. However, on a few dives, large numbers of PEEs were observed despite the fact that the seals were travelling in a nearly constant direction, suggesting a more dispersed prey resource, possibly E. antarctica. In Antarctic waters, krill is also observed within the first $100 \mathrm{~m}$ of the water column, and could be targeted by some seals feeding close to the surface during the day, as krill is suspected to be preyed upon by some seals (Y. Cherel pers. comm.).
The lack of relationship between the mean $T_{200}$ encountered by the SES during their foraging trip and either the absolute mass gain or the daily mass gain is supportive of a change in prey quality and/or size according to the water masses visited. This suggests that the lower catch rate observed in warmer waters, as well as the greater proportion of the swimming effort allocated to a greater diving depth to access those prey, might be compensated by the consumption of larger and/or higher quality prey in those water masses. For example, larger myctophids such as Gymonoscopelus piabilis, G. nicholsi and possibly G. bolini may represent a major component of SES female diet in these warmer northern waters. Indeed, in a recent study, G. Richard, J. V.-G. J. Jouma'a, C. G. (unpubl. data) found that the decrease in SES density (i.e. increase of lipid content) was positively related to the number of PEEs and was found to vary according to the foraging habitat. SES foraging north of the SAF improved their body condition at a similar rate compared with those foraging further south, despite a lower PEE rate and a greater swimming effort due to greater diving depth. This result is supportive of the hypothesis that SES females foraging north of the SAF were likely to feed on larger prey items, such as Gymnoscopelus spp., compared with those foraging south of the SAF.

Another interesting finding of this study regarding foraging success was that PEE rate both during the dive and at the bottom of the dive varied according to diurnal rhythm, with SES being more efficient during twilight compared with at night and during the day. Individuals were also found to have a significantly higher PEE rate at night compared with during the day. While we were expecting a lower foraging efficiency during daytime dives (complete dive) due to the greater diving depths recorded, we were not expecting such differences when only taking into account the PEE rate calculated at the bottom of the dive. In fact, we were expecting the opposite relationship, with a greater success rate during the bottom phases of daytime dives. Indeed, while some myctophids species are known to be actively feeding during both day and night, several studies have shown that during the day myctophids tend to aggregate in denser schools, behaving more lethargically, possibly making them more vulnerable to predation (Barham 1966, Kinzer et al. 1993, Kaartvedt et al. 2009). The present study suggests the opposite, indicating that elephant seals might be more efficient when their prey is supposedly actively foraging at night closer to the surface or performing nycthemeral migrations. Therefore, we hypothesise that actively, 
vertically migrating (at dusk and dawn) and/or foraging myctophids (at night) are easier to detect and/or locate, either because they reach aggregation levels allowing the maximization of encounter rates by predators or because their active behaviour makes them more vulnerable to predation. Actively moving prey might be easier to locate by the foraging seals. Indeed, as prey move they create hydrodynamic trails likely to be detected by SES through their vibrissae (Dehnhardt et al. 2001).

Alternatively, a recent modelling study has shown that predators reach their maximum PEE efficiency at intermediate aggregation levels of prey, with highly aggregated patches being too difficult to locate, while dispersed prey are diluted in the environment and do not allow the predator to be efficient (Massardier 2013).

Prey may also produce sounds detected by elephant seals, which are known to have excellent underwater hearing ability (Kastak \& Schusterman 1998). Indeed, over a 12-yr study, McCauley \& Cato (pers. comm.) found recently that fish choruses, most likely to be myctophids, always occurred shortly after dusk and pre-dawn, with most energy in the $1-3 \mathrm{kHz}$ range. Furthermore, while active, myctophids might be more likely to signal their presence by producing bioluminescence that seals could detect visually (Vacquié-Garcia et al. 2012). Such hypotheses should be further investigated in future studies and should provide new and valuable insights into the ecology and distribution of SES prey.

Acknowledgements. This study is part of a national research program (no. 109, H. Weimerskirch and the observatory Mammifères Explorateurs du Milieu Océanique, MEMO SOERE CTD 02) supported by the French Polar Institute (Institut Paul Emile Victor, IPEV). This work was carried out in the framework of the ANR Blanc MYCTO-3D-MAP and ANR VMC 07: IPSOS-SEAL programs and CNES-TOSCA program ('Élephants de mer océanographes'). The authors also thank the Total Foundation for financial support. All animals in this study were treated in accordance with the IPEV ethical and Polar Environment Committees guidelines. We thank all the people who contributed to the field work and data processing, with special thought to M. Authier, A. Chaigne, Q. Delorme, N. El Skaby, J. C. Vaillant and F. Vivier. We are extremely grateful to the 3 anonymous referees for their constructive suggestions and the detailed corrections provided.

\section{LITERATURE CITED}

Ancel A, Horning M, Kooyman GL (1997) Prey ingestion revealed by oesophagus and stomach temperature recordings in cormorants. J Exp Biol 200:149-154

Ansorge IJ, Froneman PW, Pakhomov EA, Lutjeharms JRE,
Perissinotto R, van Ballegooyen RC (1999) Physical-biological coupling in the waters surrounding the Prince Edward Islands (Southern Ocean). Polar Biol 21:135-145

Ashwell Erickson S, Elsner R (1981). The energy cost of free existence for Bering Sea harbour and spotted seals. In: Hood DW, Calder JA (eds) Eastern Bering Sea Shelf: oceanography and resources, Vol II. University of Washington Press, Seattle, WA, p 869-899

Authier M, Ponchon A, Martin C, Bentaleb I, Guinet C (2012) Foraging fidelity as a recipe for a long life: foraging strategy and longevity in male southern elephant seals. PLoS ONE 7:e32026

Bailleul F, Authier M, Ducatez S, Roquet F, Charrassin JB, Cherel Y, Guinet C (2010) Looking at the unseen: combining animal bio-logging and stable isotopes to reveal a shift in the ecological niche of a deep-diving predator. Ecography 33:709-719

Baker A (1954) The circumpolar continuity of Antarctic plankton species. Discov Rep 27:201-218

> Barham EG (1966) Deep scattering layer migration and composition: observations from a diving saucer. Science 151: 1399-1403

Batty R, Blaxter J, Richard J (1990) Light intensity and the feeding behaviour of herring, Clupea harengus. Mar Biol 107:383-388

Belkin IM, Gordon AL (1996) Southern Ocean fronts from Greenwich meridian to Tasmania. J Geophys Res 101: 3675-3696

Bennett KA, McConnell BJ, Fedak MA (2001) Diurnal and seasonal variations in the duration and depth of the longest dives in southern elephant seals (Mirounga leonina): possible physiological and behavioural constraints. J Exp Biol 204:649-662

Biuw M, Boehme L, Guinet C, Hindell M and others (2007) Variations in behaviour and condition of a Southern Ocean top predator in relation to in situ oceanographic conditions. Proc Natl Acad Sci USA 104:13705-13710

> Biuw M, Nøst OA, Stien A, Lydersen C, Kovacs K (2010) Effect of hydrographic variability on the spatial, seasonal and diel diving patterns of southern elephant seals in the eastern Weddell sea. PLoS ONE 5:e13816

Boden BP, Kampa EM (1967) The influence of natural light on the vertical migrations of an animal community in the sea. Symp Zool Soc 19:15-26

Boehlert GW, Costa DP, Crocker DE, Green P, O'Brien T, Levitus S, Le Boeuf BJ (2001) Autonomous pinniped environmental samplers: using instrumented animals as oceanographic data collectors. J Atmos Ocean Technol 18:1882-1893

> Bost CA, Cotté C, Bailleul F, Cherel Y and others (2009) The importance of oceanic fronts to marine birds and mammals of the southern oceans. J Mar Syst 78:363-376

> Carbone C, Houston AI (1994) Patterns in the diving behavior of the pochard, Aythya ferina: a test of an optimality model. Anim Behav 48:457-465

> Catul V, Gauns M, Karuppasamy PK (2011) A review on mesopelagic fishes belonging to family Myctophidae. Rev Fish Biol Fish 21:339-354

Charrassin JB, Kato A, Handrich Y, Sato K and others (2001) Feeding behaviour of free-ranging penguins determined by oesophageal temperature. Proc Biol Sci 268:151-157

Charrassin JB, Hindell M, Rintoul SR, Roquet F and others (2008) Southern Ocean frontal structure and sea-ice formation rates revealed by elephant seals. Proc Natl Acad Sci USA 105:11634-11639 
Cherel Y, Ducatez S, Fontaine C, Richard P, Guinet C (2008) Stable isotopes reveal the trophic position and mesopelagic fish diet of female southern elephant seals breeding on the Kerguelen Islands. Mar Ecol Prog Ser 370: 239-247

Collins MA, Xavier JC, Johnston NM, North AW and others (2008) Patterns in the distribution of myctophid fish in the northern Scotia Sea ecosystem. Polar Biol 31:837-851

Costa DP, Klinck JM, Hofmann EE, Dinniman MS, Burns JM (2008) Upper ocean variability in West Antarctic Peninsula continental shelf waters as measured using instrumented seals. Deep-Sea Res II 55:323-337

Cotté C, Simard Y (2005) Formation of dense krill patches under tidal forcing at whale feeding hot spots in the St. Lawrence Estuary. Mar Ecol Prog Ser 288:199-210

Crocker DE, Le Boeuf BJ, Costa DP (1997) Drift diving in female northern elephant seals: implication for food processing. Can J Zool 75:27-39

Daneri GA, Carlini AR (2002) Fish prey of southern elephant seals, Mirounga leonina, at King George Island. Polar Biol 25:739-743

> Dehnhardt G, Mauck B, Hanke W, Bleckmann H (2001) Hydrodynamic trail following in harbor seals (Phoca vitulina). Science 293:102-104

> Dodson S (1990) Prediciting diel vertical migration of zooplankton. Limnol Oceanogr 35:1195-1200

> Dragon AC, Monestiez P, Bar-Hen A, Guinet C (2010) Linking foraging behaviour to physical oceanographic structures: southern elephant seals and mesoscale eddies east of Kerguelen Islands. Prog Oceanogr 87:61-71

> Dragon AC, Bar-Hen A, Monestiez P, Guinet C (2012) Horizontal and vertical movements as predictors of foraging success in a marine predator. Mar Ecol Prog Ser 447: 243-257

Fielding S, Watkins JL, Collins MA, Enderlein P, Venables HJ (2012) Acoustic determination of the distribution of fish and krill across the Scotia Sea in spring 2006, summer 2008 and autumn 2009. Deep-Sea Res II 59-60: 173-188

Gal GL, Ellis R, Rudstam LG, Mohammadian AM (1999) Light and diel vertical migration: spectral sensitivity and light avoidance by Mysis relicta. Can J Fish Aquat Sci 56: 311-322

Gallon S, Bailleul F, Charrassin JB, Guinet C, Bost CA, Handrich Y, Hindell M (2013) Identifying foraging events in deep diving southern elephant seals, Mirounga leonina, using acceleration data loggers. Deep-Sea Res II 88-89:14-22

Gjosaeter J, Kawaguchi K (1980) A review of the world resources of mesopelagic fish. FAO Fish Tech Pap 193: $1-151$

Guinet C, Cherel Y, Ridoux V, Jouventin P (1996) Consumption of marine resources by seabirds and seals in Crozet and Kerguelen waters: changes in relation to consumer biomass 1962-1985. Antarct Sci 8:23-30

Guinet C, Walker E, Monestiez P, Xing X and others (2013) Assessment of phytoplankton concentration in the Southern Ocean by elephant seal equipped with a new generation of CTD-fluorescence tags. Earth Syst Sci Data 5:15-29

> Hanuise N, Bost CA, Handrich Y (2013) Optimization of transit strategies while diving in foraging king penguins. J Zool 290:181-191

> Hassrick JL, Crocker DE, Teutschel NM, McDonald BI, Robinson PW, Simmons SE, Costa DP (2010) Condition and mass impact oxygen stores and dive duration in adult female northern elephant seals. J Exp Biol 213: 585-592

> Hindell MA, Slip DJ, Burton HR (1991) The diving behaviour of adult male and female southern elephant seals, Mirounga leonina (Pinnipedia: Phocidae). Aust J Zool 39: 595-619

Hindell MA, Bradshaw CJA, Sumner MD, Michael KJ, Burton HR (2003) Dispersal of female southern elephant seals and their prey consumption during the austral summer: relevance to management and oceanographic zones. J Appl Ecol 40:703-715

Horning M, Trillmich F (1999) Lunar cycles in diel prey migrations exert a stronger effect on the diving of juveniles than adult Galapagos fur seals. Proc R Soc Lond B Biol Sci 266:1127-1132

Hulley PA (1981) Results of the research cruises of FRV 'Walther Herwig' to South America. LVIII. Family Myctophidae (Osteichthyes, Myctophiformes). Arch FischWiss 31:1-300

Hulley PA (1986) Myctophidae. In: Smith MM, Heemstra PC (eds) Smiths' sea fishes. Springer-Verlag, Berlin, p 282321

Hulley PA (1990) Family Myctophidae. In: Gon O, Heemstra PC (eds) Fishes of the Southern Ocean. JLB Smith Institute of Ichthyology Publishers, Grahamstown, p 146-178

Hulley PA, Lutjeharms JRE (1995) The south-western limit for the warm-water, mesopelagic ichthyofauna of the Indo-West-Pacific: lanternfish (Myctophidae) as a case study. S Afr J Mar Sci 15:185-205

Iwata T, Sakamoto KQ, Takahashi A, Edwards EWJ, Staniland IJ, Trathan PN, Naito Y (2012) Using a mandible accelerometer to study fine-scale foraging behavior of free-ranging Antarctic fur seals. Mar Mamm Sci 28: 345-357

Jaud T, Dragon AC, Garcia JV, Guinet C (2012) Relationship between chlorophyll a concentration, light attenuation and diving depth of the southern elephant seal Mirounga leonina. PLoS ONE 7:e47444

Jeanniard du Dot T, Rosen DAS, Trites AW (2008) Steller sea lions show diet-dependent changes in body composition during nutritional stress and recover more easily from mass loss in winter than in summer. J Exp Mar Biol Ecol 367:1-10

> Kaartvedt S, Røstad A, Klevjer TA, Staby A (2009) Use of bottom-mounted echo sounders in exploring behavior of mesopelagic fishes. Mar Ecol Prog Ser 395:109-118

Kampa EM (1976) Photoenvironment and vertical migrations of mesopelagic marine animal communities. In: De Coursey PJ (ed) Biological rhythms in the marine environment. Belle W Baruch Library in Marine Sciences, University of South Carolina Press, Columbia, SC, p 257-272

Kastak D, Schusterman RJ (1998) In-air and underwater hearing sensitivity of a northern elephant seal (Mirounga angustirostris). Can J Zool 77:1751-1758

Kinzer J, Bottger-Schnack R, Schulz K (1993) Aspects of horizontal distribution and diet of myctophid fish in the Arabian Sea with reference to the deep water oxygen deficiency. Deep-Sea Res II 40:783-800

Knox GA (2007) Biology of the Southern Ocean, 2nd edn. CRC Press, Boca Raton, FL

Kock KH (1992) Antarctic fish and fisheries. Cambridge University Press, Cambridge

Koubbi P (1993) Inflence of the frontal zones on ichthyo- 
plankton and mesopelagic assemblages in the Crozet Basin (Indian sector of the Southern Ocean). Polar Biol 13:557-564

Koubbi P, Moteki M, Duhamel G, Goarant A and others (2011) Ecoregionalization of myctophid fish in the Indian sector of the Southern Ocean: results from generalized dissimilarity models. Deep-Sea Res II 58:170-180

> Lea MA, Cherel Y, Guinet C, Nichols PD (2002a) Antarctic fur seals foraging in the Polar Frontal Zone: inter-annual shifts in diet as shown from fecal and fatty acid analyses. Mar Ecol Prog Ser 245:281-297

Lea MA, Nichols PD, Wilson G (2002b) Fatty acid composition of lipid-rich myctophids and mackerel icefish (Champsocephalus gunnari) Southern Ocean food-web implications. Polar Biol 25:843-854

Lea MA, Johnson D, Melin S, Ream R, Gelatt T (2010) Diving ontogeny and lunar responses in a highly migratory mammal, the northern fur seal Callorhinus ursinus. Mar Ecol Prog Ser 419:233-247

Liebsch N, Wilson RP, Bornemann H, Adelung D, Plötz J (2007) Mouthing off about fish capture: jaw movement in pinnipeds reveals the real secrets of ingestion. Deep-Sea Res II 54:256-269

Liu SH, Sun S, Han BP (2003) Diel vertical migration of zooplankton following optimal food intake under predation. J Plankton Res 25:1069-1077

Lubimova TG, Shust KV, Popkov VV (1987) Specific features in the ecology of Southern Ocean mesopelagic fish of the family Myctophidae. Biological resources of the Arctic and Antarctic (collected papers). Nauka Press, Moscow, p 320-337 (in Russian)

Massardier L (2013) Etude de la faisabilité du couplage d'un modèle océanique et d'un modèle individu centré en vue de la simulation du comportement de grands prédateurs en zone australe. MSc thesis, Université Nice Sophia Antipolis

McIntyre T, De Bruyn PJN, Ansorge IJ, Bester MN, Bornemann H, Plötz J, Tosh CA (2010) A lifetime at depth: vertical distribution of southern elephant seals in the water column. Polar Biol 33:1037-1048

> McIntyre T, Bornemann H, Plötz J, Tosh CA, Bester MN (2011a) Water column use and forage strategies of female southern elephant seals from Marion Island. Mar Biol 158:2125-2139

McIntyre T, Ansorge IJ, Bornemann H, Plötz J, Tosh CA, Bester MN (2011b) Elephant seal dive behaviour is influenced by ocean temperature: implications for climate change impacts on an ocean predator. Mar Ecol Prog Ser 441:257-272

McMahon CR, Burton H, Slip D, McLean S, Bester M (2000) Field immobilisation of southern elephant seals with intravenous tiletamine and zolazepam. Vet Rec 146: 251-254

Morel A (1988) Optical modeling of the upper ocean in relation to its biogenous matter content (case I waters). J Geophys Res 93:10749-10768

Naito Y, Bornemann H, Takahashi A, McIntyre T, Plotz J (2010) Fine-scale feeding behaviour of Weddell seals revealed by mandible accelerometer. Polar Sci 4: 309-316

Naito Y, Costa DP, Adachi T, Robinson PW, Fowler M, Takahashi A (2013) Unravelling the mysteries of a mesopelagic diet: a large apex predator specializes on small prey. Funct Ecol 27:710-717

Orsi AH, Whiteworth IT, Nowlin WD Jr (1995) On the meri- dional extent and fronts of the Antarctic Circumpolar Current. Deep-Sea Res I 42:641-673.

Park YH ,Gambéroni L, Charriaud E (1991) Frontal structure, transport and variability of the Antarctic Circumpolar Current in the South Indian Ocean sector, $40^{\circ}-80^{\circ} \mathrm{E}$. Mar Chem 35:45-62

> Park YH, Gambéroni L, Charriaud E (1993) Frontal structure, water masses, and circulation in the Crozet Basin. J Geophys Res 98:12361-12385

> Park YH, Charriaud E, Fieux M (1998) Thermohaline structure of the Antarctic surface water/winter water in the Indian sector of the Southern Ocean. J Mar Syst 17:5-23

R Development Core Team (2009) R: a language and environment for statistical computing. R Foundation for Statistical Computing, Vienna

Ropert-Coudert Y, Wilson RP (2005) Trends and perspectives in animal-attached remote sensing. Front Ecol Environ 3:437-444

Ropert-Coudert Y, Kato A, Liebsch N, Wilson RP, Müller G, Baubet E (2004) Monitoring jaw movements: a cue to feeding activity. Game Wildl Sci 20:1-19

> Roquet F, Park YH, Guinet C, Bailleul F, Charrassin JB (2009) Observations of the Fawn Trough Current over the Kerguelen Plateau from instrumented elephant seals. J Mar Syst 78:377-393

Rosen DAS, Trites AW (1999) Metabolic effect of low-energy diet on Steller sea lions, Eumetopias jubatus. Physiol Biochem Zool 72:723-731

Rudstam LG, Danielsson K, Hansson S, Johansson S (1989) Diel vertical migration and feeding patterns of Mysis mixta (Crustacea, Mysidacea) in the Baltic Sea. Mar Biol 101:43-52

> Rutz C, Hays GC (2009) New frontiers in biologging science. Biol Lett 5:289-292

Sabourenkov E (1991) Myctophids in the diet of Antarctic predators. CCAMLR Selected Sci Pap 1991:335-368

Slip DJ (1995) The diet of southern elephant seals (Mirounga leonina) from Heard island. Can J Zool 73: 1519-1528

Suzuki I, Naito Y, Folkow LP, Miyazaki N, Blix AS (2009) Validation of a device for accurate timing of feeding events in marine animals. Polar Biol 32:667-671

> Vacquié-Garcia J, Royer F, Dragon AC, Viviant M, Bailleul F, Guinet C (2012) Foraging in the darkness of the Southern Ocean: influence of bioluminescence on a deep diving predator. PLoS ONE 7:e43565

Viviant M, Trites AW, Rosen DAS, Monestiez P, Guinet C (2010) Prey capture attempts can be detected in Steller sea lions and other marine predators using accelerometers. Polar Biol 33:713-719

Wilson RP, Cooper J, Plötz J (1992) Can we determine when marine endotherm feed? A case study with seabirds. J Exp Biol 167:267-275

Wilson RP, Steinfurth A, Ropert-Coudert Y, Kato A, Kurita M (2002) Lip-reading in remote subjects: an attempt to quantify and separate ingestion, breathing and vocalisation in free-living animals using penguins as a model. Mar Biol 140:17-27

Zasel'sliy VS, Kudrin BD, Poletayev VA, Chechenin S (1985) Some features of the biology of Electrona carlsbergi (Taning) (Myctophidae) in the Atlantic sector of the Antarctic. J Ichthyol 25:163-166

Zuur AF, Ieno EN, Walker NJ, Saveliev AA, Smith GM (2009) Mixed effects models and extensions in ecology with R. Springer, New York, NY 